\section{Application of Reverse Micelles for the Extraction of Amino Acids and Proteins}

\author{
Martin E. Leser and Pier Luigi Luisi*
}

\begin{abstract}
The use of water-in-oil microemulsions for the solubilization and extraction of amino acids and proteins is investigated, using both the liquid-liquid extraction and the solid-liquid extraction method. The solubilization behaviour of small monomeric proteins such as cytochrome c, lysozyme, ribonuclease A, trypsin, $\alpha$-chymotrypsin, papain, pepsin, and bovine serum albumin (BSA) into mainly AOT (the anionic surfactant bis(2-ethylhexyl) sodium sulfosuccinate) $/ \mathrm{H}_{2} \mathrm{O} /$ isooctane is studied by varying several external parameters, such as $w_{0}\left(w_{0}=\left[\mathrm{H}_{2} \mathrm{O}\right] /[\mathrm{AOT}]\right)$, surfactant type and concentration in the organic phase, and, $\mathrm{pH}$, ionic strength, salt type in the $\mathrm{H}_{2} \mathrm{O}$ phase. In the liquid-liquid extraction method, the present biphasic system consists of an aqueous and a supernatant reverse micellar solution. The compounds are transferred from the $\mathrm{H}_{2} \mathrm{O}$ phase into the organic micellar phase. This process is investigated also in view of the simultaneously occurring $\mathrm{H}_{2} \mathrm{O}$ transfer. Studies of transfer kinetics give an information about the connection between the $\mathrm{H}_{2} \mathrm{O}$ and protein extraction. In the second technique, the compounds are given in their solid state and suspended in the organic micellar solution which contains already a known amount of solubilized water.

With the liquid-liquid phase-transfer method, it is shown that, under certain conditions, a quantitative and quite remarkable transfer can be achieved, whereby the salt type and its concentration in the $\mathrm{H}_{2} \mathrm{O}$ phase, as well as the aqueous $\mathrm{pH}$, play the most important role in determining the extent mass transfer. The significance of electrostatic interactions between the micelles and the extracted molecules is evidenced also by comparing extraction results obtained with $\mathrm{AOT}$ and $\mathrm{CTAB}$ (cetyltrimethylammonium bromide; is a cationic surfactant) water-in-oil microemulsions. Moreover, the extraction yield of a series of positively, negatively charged, and neutral amino-acid derivatives is investigated in the two surfactant systems, in order to characterize the significance of electrostatic and hydrophobic interactions with the surfactant molecules. This series of amino-acid derivatives is also studied with the solid-phase extraction method. In the case of proteins transferred from the solid state, the solubilization yield is affected by the protein and micellar droplet size. For small proteins, i.e. with a molecular weight below ca. $15000 \mathrm{D}$, the extraction curve as a function of $w_{\circ}$ shows surprisingly enough a peak in the small $w_{0}$ region (between 6 and 12). By increasing the $\mathrm{H}_{2} \mathrm{O}$ content above this $w_{0}$ limit, the transfer efficiency of the $\mathrm{H}_{2} \mathrm{O}$-soluble proteins decreases. For proteins having a molecular weight above $20000 \mathrm{D}$, the extraction curve as a function of $w_{0}$ shows a monotonous increase with increasing $w_{0}$ without any sharp $w_{0}$ maxima. A qualitative model is offered to explain this different behaviour. It is also shown that the ionization state of commercially available protein powders markedly affects the extraction behaviour. The micellar exclusion effect is finally applied in the extraction of proteins from a crude bacterial protein mixture.
\end{abstract}

\section{General Introduction}

The observation that a great variety of proteins (i.e. enzymes) can be easily solubilized into water-in-oil microemulsions has acquired in recent years biotechnological relevance in different ways [1]. One promising application of reversed micelles is attributed to the enzymatic conversion of $\mathrm{H}_{2} \mathrm{O}$-insoluble substrates [1-3]. Equally interesting and somewhat closer to large- scale applications is the extraction and purification of proteins or other bioproducts from fermentation and cell culture media. Because of the interest in the development of new concepts in the separation and purification technology, reverse micelles gained increased attention in this field [4]. In fact, several research groups are working today in this area, most notably those of Hatton at M.I.T. (USA) [5-11], van't Riet, Hilhorst, and Laane in Wageningen

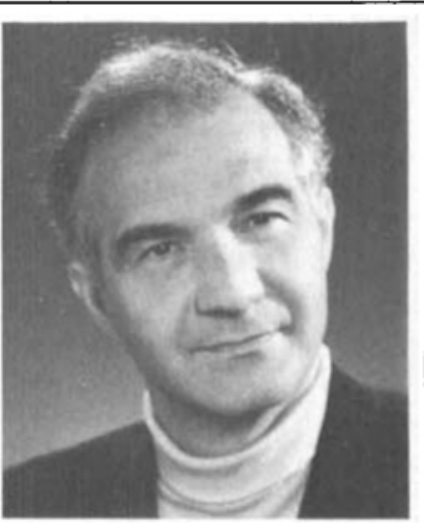

Pier Luigi Luisi: Born May 23, 1938 in Piombino, Italy; Italian nationality.

- December 1963: 'Dottore in chimica' (cum laude) at the University of Pisa, Italy as a student of the Scuola Normale Superiore. The Doctor thesis was carried out partly in Pisa under the direction of Prof. P. Pino and partly at the Institute of High Molccular Weight Compounds in Leningrad, under the direction of Prof. M.V. Volkenstein and T.M. Birshtein.

- March 1964: 'Diploma in chimica' (cum laude) at the Scuola Normalc Superiore in Pisa.

1963-1967: Assistent at the Institute of Organic Chemistry of the University of Pisa, in the group of Prof. P. Pino, and at the Scuola Normale Superiore.

During the above mentioned period, post-doctoral stages in Uppsala, in the group of Prof. Claesson, and at the Macromolecular Center in Strassburg.

1967-1969: Research-Fellow at the Institute of Molecular Biology, Eugene, Oregon, USA, with Prof. S. A. Bernhard.

Since September 1969 at the Technisch-Chemisches Laboratorium, ETH, Zürich, as Oberassistent.

Since 1971 'Privatdozent' in macromolecular chemistry.

Since Summer Semester 1972, 'Assistenz-Professor' of macromolecular chemistry.

- Since Summer Semester $1980^{\circ}$ Ausserordentlicher Professor' in the same Department.

During Summer Semester 1983, sabbatical teave, and Visiting Professor at the University of Tennessee in Knoxville, Visiting Professor at Harvard University and Visiting Professor in Hefei and other Chinese Universities under the invitation of the Academia Sinica.

- Since October I, 1984, Ordinarius in Macromolecular Chemistry at the ETHZ.

October 1985, Honour Guest Professor at the University of Nagasaki, Japan.

April 1987, Guest Professor at the Centre d’études nucléaires de Saclay.

- October 1987, Visiting Professor at the Korean Institute of Science and 'Technology in Seoul, Korea.

(Netherlands) [12-16], Fletcher in Hull (England) [17, 18], Armstrong in Missouri (USA) [19], Maestro and Caselli in Bari (Italy) [20-24], Plucinski and Nitsch in München (Germany) [25], Renon in Paris (France) [26] and our own [22-24] [27-37].

The main purpose of this paper is to present a critical review of our own recent activity in the field. This will be done by offering a comparison with literature data. Chapt. 3 is dealing with the phase transfer

* Correspondence: Prof. P. L. Luisi Institut für Polymerc

ETH-Zentrum

Universitätstrasse 6, CH 8092 Zürich 
of amino acids or proteins from aqueous to supernatant organic reverse micellar solutions. We will mainly focus on the elucidation of the parameters controlling this extraction method. The use of reverse micelles in industrial processes is investigated mainly in the laboratories at M.I.T. [11] and in Wageningen [16] addressing principle questions concerning the process development. Chapt.4, then, is dealing with the extraction of amino acids and proteins from the solid state which is considered as an alternative potential micellar separation method. So far, only a few reports which described this technique were published [38-41]. We will present and review here most of our own data on the field, considering mainly different amino-acid derivatives and some small monomeric proteins such as lysozyme, ribonuclease A, cytochrome c, trypsin, $\alpha$-chymotrypsin, papain, pepsin, and bovine serum albumin (BSA), as well as technical mixtures of proteins in the form of meals. We will examine the influence of the micellar $\mathrm{H}_{2} \mathrm{O}$ content on both the efficiency and specificity of the solute transfer. Some of the data on proteins have been reported already in a preliminary form [33].

Before discussing the topic of this paper, it is necessary to outline general properties of reverse micelles. This will be done in the next section in a rather condensed way. For a deeper understanding of reverse micellar properties in relation to the solubilization of proteins, the reader is referred to reviews which emphasize different special aspects, i.e. physico-chemical aspects [42] [43], enzymology [42-45] and biotechnology [1] [46].

\subsection{Short Summary of Reverse Micellar Properties}

Reverse (reversed, or inverted) micellar solutions consist of aggregates which are formed spontaneously by a great variety of surfactants in different organic solvents [47]. They are thermodynamically stable (no phase separation with time) and transparent. Generally, we are dealing with a ternary system consisting of surfactant, $\mathrm{H}_{2} \mathrm{O}$, and organic solvent. Occasionally a co-surfactant is used (normally a shortchain alcohol) in order to facilitate the formation of reverse micellar aggregates or to increase the micellar $\mathrm{H}_{2} \mathrm{O}$ uptake. The central aqueous core of the micelles (also referred to as 'water pool') is surrounded by the surfactant interfacial film. The organic media makes up 60 to $90 \%$ of the total volume of the solution. When a larger amount of $\mathrm{H}_{2} \mathrm{O}$ is present ( $>2$ to $8 \%$ ), the system is described better with the term 'water-in-oil microemulsion' than with that of 'reverse micelle'. In this situation, an independent $\mathrm{H}_{2} \mathrm{O}$ microphase is formed. The term 'reverse micelle' is more properly used for a binary system (containing no $\mathrm{H}_{2} \mathrm{O}$ ), or when the low amount of $\mathrm{H}_{2} \mathrm{O}$ is bound to the micelle and does not form an independent microphase. However, in this paper we will not distinguish between these two $\mathrm{H}_{2} \mathrm{O}$ states and use all over the term 'reverse micelle'. The micellar water content is often represented by the molar ratio of $\mathrm{H}_{2} \mathrm{O}$ and surfactant $w_{\mathrm{o}}\left(w_{\mathrm{o}}=\left[\mathrm{H}_{2} \mathrm{O}\right] /\right.$ [AOT]). The physical properties of reverse micellar solutions depend mainly on this ratio. They are much less influenced by the absolute values of either the surfactant or $\mathrm{H}_{2} \mathrm{O}$ concentration.

In the following, we will describe some important and characteristic properties of organic micellar solutions taking the AOT/ $\mathrm{H}_{2} \mathrm{O} /$ isooctane microemulsion as a reference system. The term 'AOT' stands for the well known surfactant bis(2-ethylhexyl) sodium sulfosuccinate, certainly the most investigated surfactant in the reverse-micellar field. The reason for this popularity, aside from the ready availability of the material, lies mostly in the fact that it permits the formation of a reverse micellar system without addition of a co-surfactant; i.e. the water-in-oil droplets make up the dominating aggregation form in the ternary phase diagram $\left(\mathrm{L}_{2}\right.$ phase $)$. The system permits a relatively high $\mathrm{H}_{2} \mathrm{O}$ solubilization $\left(w_{\mathrm{o}, \max } \approx 55\right)$. The solubilization capacity is, however, dependent on the nature of the used oil phase.

AOT form reverse micelles which are spherical and only slightly polydispers aggregates [48]. Their dimensions depend linearly on $w_{\mathrm{o}}$. The water pool radius $r_{\mathrm{wp}}$ (defined as the micellar radius without the hydrophobic surfactant tails) can be approximated according to the following relationship [43]:

$r_{\text {wp }}[\AA]=1.75 w_{\mathrm{o}}$

Thus, for example at $w_{\mathrm{o}}=30, r_{\mathrm{wp}}$ is $53 \AA$; adding to it the length of the AOT tail ( $\mathrm{ca}$. $12 \AA$ ) the total diameter of an aggregate is ca. $130 \AA$.

The water in the water pool is often referred to as 'anomalous', in the sense that it displays physico-chemical properties which differ significantly, particularly at low $w_{\mathrm{o}}$ values, from those of bulk water. This is evidenced, for example, by the IR signal of $\mathrm{H}_{2} \mathrm{O}$ [49], by the 'H-NMR shift [50], or the relaxation times of the $\mathrm{H}_{2} \mathrm{O}$ protons [51], or by measurements of water activity [52], as a function of $w_{0}$. These physico-chemical properties vary asymptotically with $w_{\mathrm{o}}$ and reach a constant value (at $w_{0}$ values above 30 or higher) which is similiar but in some cases not identical to the value obtained in bulk water. Also, water of reverse micelles at low $w_{0}$ values (i.e. $\leq 10$ ) freezes well below $0^{\circ}[53]^{\circ}$.

The fact of the anomaly of $\mathrm{H}_{2} \mathrm{O}$ raises the question of the meaning of $\mathrm{pH}$ in the water pool. This problem has been debated extensively in literature (see e.g. [42] [43]). Although, strictly spoken, the concept and measurement of aqueous $\mathrm{pH}$ is disputable in reverse micellar systems, it is possible to titrate $\mathrm{H}_{2} \mathrm{O}$-soluble compounds obtaining sensible apparent pK values [54]. Furthermore, enzymatic reactions carried out in reverse micelles show a $\mathrm{pH}$ profile which is

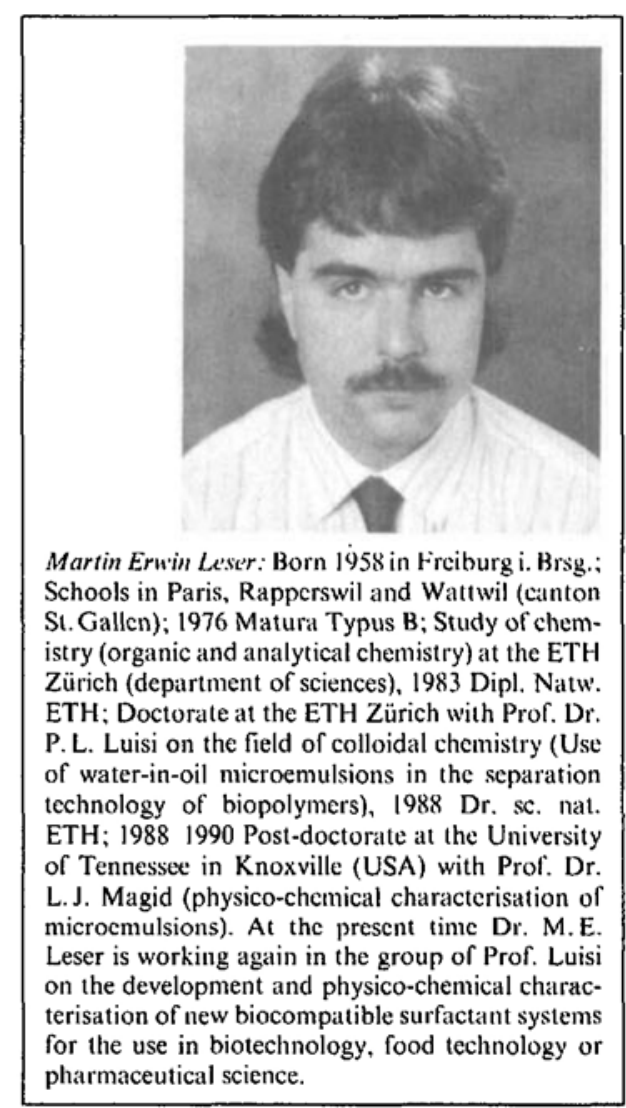

often very close to that in $\mathrm{H}_{2} \mathrm{O}$. It is assumed, therefore, that the water pool pH corresponds to the $\mathrm{pH}$ of the aqueous buffered stock solution used to prepare the enzyme containing micellar phase. However, caution is always recommended, particularly when working at low $w_{\mathrm{o}}$ values.

As already mentioned, a large number of hydrophylic substances, including macromolecules, can be solubilized into the water pool of reverse micelles. The point of interest for most chemical applications is to be seen in the capability of forming host-guest complexes in which the microenvironment can be modulated. In fact, the physical properties of the water pool can be tuned very simply, i.e. by varying the parameter $w_{\mathrm{o}}$. At the same time, also the micellar dimensions change so that it is possible to modulate the extent of the solubilization of larger molecules, such as proteins. Furthermore, the microenvironment in the water core varies with $\mathrm{pH}$, nature and concentration of added salt, surfactant type, and temperature.

Reverse micelles are highly dynamic systems [43]. The surfactant molecules in the aggregates enjoy a lot of rotational and translational freedom. Furthermore, when the micelles collide and coalesce forming a dimer, the water pools of the two aggregates exchange their contents. The micellar lifetime is a characteristic feature for each surfactant system; an AOT reverse micellar aggregate at typical conditions $\left(u_{n}^{\prime}: 10\right.$, $100 \mathrm{~mm}$ AOT in isooctane), for example, exists over ca. $1 \mathrm{~ms}[43]$. Clearly, the exchange mechanism between the aggregates define basic properties of chemical reactivity in a reversed micellar system. 


\section{Introducing the Field of Protein Extraction Using Reverse Micelles}

\subsection{The Liquid-Liquid Phase-Transfer Method}

Several years ago, first experiments using organic surfactant solutions for the extraction of biological active compounds were made in order to investigate the transport phenomenon of solute molecules through biological membranes. Behr and Lehn [55], for example, used a model system consisting of two aqueous solutions, being separated by an organic phase which contained a certain amount of surfactant. They assumed that the surfactant (in this case TOMAC (trioctylmethylammonium chloride)) acted as a carrier for different amino acids and dipeptides. The peptides were initially solved in a water phase with a basic $\mathrm{pH}$, complexed at the oil-water interface and transported through the organic liquid membrane (consisting of toluene and surfactant) into an other aqueous solution having an acidic $\mathrm{pH}$. Several years later, Dossena et al. [27] started a systematic investigation of this 'tri-phasic' model system by focussing on the distribution determination of different peptide molecules in a bi-phasic system, i.e. the transfer from an aqueous solution into an organic surfactant phase. The extraction efficiency of the $\mathrm{H}_{2} \mathrm{O}$-soluble peptides into organic solutions was thereby surprisingly good. It was found that this experimental configuration represents a simple method to solubilize small molecules into organic surfactant solutions. This method was referred to as 'liquid-liquid phase transfer' or 'phasetransfer method'. The technique was also feasible for the successful solubilization of macromolecules (such as proteins) into organic surfactant media [28] [29]. The formed reverse micellar aggregates were thereby considered to be responsible for the good solubilization of the guest molecules into the organic phase and their transport through the organic membrane. The tri-phase system was also referred to as 'double transfer' [29].

First phase-transfer experiments with proteins were carried out with TOMAC/ $\mathrm{H}_{2} \mathrm{O} /$ cyclohexane systems [27-29]. Beside the elucidation of the spectroscopic properties of different peptides and proteins in the novel organic media, it was interesting to observe that the solubilization of proteins is a selective process. Each of the proteins under investigation (i.e. $\alpha$-chymotrypsin, trypsin, pepsin, lysozyme or chymotrypsinogen) was extracted with a characteristic efficiency into the micellar solution. For example, under conditions of maximum extraction of $\alpha$-chymotrypsin (pH 10, unbuffered solution), less than 5\% of the lysozyme was solubilized, while peroxidase or chymotrypsinogen were not transferred at all [29]. Although the parameters effecting mostly the transfer efficiency were not investigated in a systematic way, it was demonstrated for the first time that the phase-transfer method ex-

Table 1. Some Structural Properties of Proteins Investigated in the Present Work (all data from [57])

\begin{tabular}{|c|c|c|c|c|c|c|c|}
\hline \multirow[t]{2}{*}{ Protein } & \multirow{2}{*}{$\begin{array}{l}\text { Molecular } \\
\text { weight [D] }\end{array}$} & \multirow[t]{2}{*}{$\left.\mathrm{pl}^{\mathrm{q}}\right)$} & \multirow{2}{*}{$\begin{array}{l}\left.r_{0}^{b}\right) \\
{[\AA]}\end{array}$} & \multicolumn{2}{|c|}{ Total protein charge ${ }^{c}$ ) } & \multicolumn{2}{|c|}{ (harge density) } \\
\hline & & & & $\mathrm{pH} 3$ & $\mathrm{pH} 9$ & $\mathrm{pH} 3$ & $\mathrm{pH} 9$ \\
\hline $\begin{array}{l}\text { Cytochrome c } \\
\text { Ribonuclease A } \\
\text { Lysozyme } \\
\text { Papain } \\
\text { Trypsin } \\
\alpha \text {-Chymotrypsin } \\
\text { Pepsin } \\
\text { BSA }\end{array}$ & $\begin{array}{l}12500 \\
13700 \\
14400 \\
23800 \\
23800 \\
25000 \\
35000 \\
66000\end{array}$ & $\begin{array}{r}10.6 \\
9.5 \\
11.0 \\
9.6 \\
10.8 \\
9.1 \\
1.0 \\
4.8\end{array}$ & $\begin{array}{l}15.3 \\
15.8 \\
15.8 \\
18.9 \\
\\
\\
19.4 \\
21.8 \\
26.8\end{array}$ & $\begin{array}{c}25+ \\
19+ \\
19+ \\
25+ \\
21+ \\
20+ \\
5+\end{array}$ & $\begin{array}{l}8+ \\
3+ \\
6+ \\
7+ \\
5+ \\
3+\end{array}$ & $\begin{array}{r}13.0+ \\
9.6+ \\
9.6+ \\
10.5+\end{array}$ & $\begin{array}{l}4.2+ \\
1.5+ \\
3.0+ \\
3.0+\end{array}$ \\
\hline
\end{tabular}

a) Isoelectric point.

Anhydrous hydrodynamic radius; calculated according to the relation: $r_{0}=\left[\left(3 M_{\mathrm{r}} \cdot v_{2}\right) /\left(4 \pi \cdot N_{0}\right)\right]^{1 / 3}$ $M_{\mathrm{f}}$ : molecular weight; $v_{2}$ : partial specific volume $\left[\mathrm{cm}^{3} / \mathrm{g}\right] ; N_{\mathrm{o}}:$ Avogadro number.

Protein net charge determined by 'counting' the charged amino-acid residues (Lys, Arg, His, Asp, Glu, carboxy - and amino - end) in the primary structure. It is assumed that they are located all on the protein surface.

d) Protein net charge per $\AA^{2}$ protein surface: (net charge $\left./\left(4 \pi r_{o}^{2}\right)\right) \cdot 10^{-2}$.

hibits principally a potential application in the separation technology of proteins.

The phase-transfer technique was extended also to other surfactant system i.e. mainly to $\mathrm{AOT} / \mathrm{H}_{2} \mathrm{O} /$ hydrocarbon microemulsions [29-31]. Today, AOT is the most widely used surfactant in the field of micellar protein extraction.

Amino acids or protein(s) solubilized in reverse micellar solutions can be transferred back into an aqueous solution. The experimental configuration has been referred to as 'Backward (or back) transfer method'. It is the reverse of the above described 'forward transfer method' [29] [30]: a two-phase system is used in which the protein-containing micellar solution is superimposed onto an aqueous solution containing a high concentration of a particular salt. It was assumed that the salt in the $\mathrm{H}_{2} \mathrm{O}$ phase exchanges with the protein initially present in the micelles, and that it expelles the protein molecules out of the micelles into the conjugated aqueous solution.

\subsection{The Solid-Liquid Phase Extraction Method}

The extraction of amino acids or proteins from the solid state is another experimental possibility to solubilize them into reverse micelles. In this method, the amino acid or protein powder (or a mixture of proteins) is suspended in a micellar solution and mildly stirred. The micellar solution contains already a known initial amount of $\mathrm{H}_{2} \mathrm{O}$. It was observed that the initial $w_{\mathrm{o}}$ value is an important parameter which determines significantly the extraction efficiency [32]. This extraction technique is referred to as 'solid (liquid)-phase extraction method'. The method was described first for the extraction of $\alpha$-chymotrypsin by Menger et al. [56]. It was used then by other groups to solubilize different other $\mathrm{H}_{2} \mathrm{O}$-soluble proteins such as myelin basic protein MBP [40], lysozyme [32] [38], peroxidase [39], or $\alpha$-chymotrypsin [38] into AOT reverse micellar solutions. A systematical investigation, however, of the solubilization mechanism was not accomplished so far.

The solid-phase extraction technique is the only possible method which allows also the solubilization of $\mathrm{H}_{3} \mathrm{O}$-insoluble proteins [41]. Moreover, it appears advantageous for the biotechnological treatment of meals and other farinaceous natural products containing in general a large mixture of proteins [36].

We will see in the following that the solubilization behaviour of different proteins is not only affected by the characteristics of the used microemulsion system but also by intrinsic properties of each protein. The main protein parameters which seem to be important in this context are summarized in Table 1: the isoelectric point pI, the molecular weight $M_{\mathrm{r}}$, the hydrodynamic radius $r_{0}$, and the charge density on the protein surface (determined at a hypothetical $\mathrm{pH}$ of 3 and 9).

\section{Liquid-Liquid Phase Transfer from Aqueous Solutions}

\subsection{Transfer of Proteins}

\subsection{Kinetics of Protein Transfer}

First aspect to be considered in the liquidliquid phase-transfer experiments is the velocity of solute transfer from an aqueous into an organic micellar phase, i.e. the time necessary to reach the equilibrium distribution between the two phases. Initially the compounds were present in the aqueous phase. In this section, we will report data obtained with three different proteins. Beside the protein transfer kinetics, it was also interesting to follow the simultaneous $\mathrm{H}_{2} \mathrm{O}$ transfer into the organic phase. Using the 'gentle' shaking technique which avoids mechanical mixing of the two phases (no emulsion is formed; see Experimental), it is possible to get a correlation of their kinetics. This aspect has not been considered in detail in literature so far.

The results are summarized in Fig. I which shows the time progress of the solubilization of lysozyme, ribonuclease $A$, and trypsin into a $50 \mathrm{mM}$ AOT/isooctane phase from a buffered (pH 5) aqueous solution containing $0.1 \mathrm{M} \mathrm{CaCl}_{2}$ (Fig. 1A) and the simultaneously occurring $\mathrm{H}_{2} \mathrm{O}$-transfer kinetics (Fig. IB). The solubilization rates for lysozyme and ribonuclease $A$ is almost 

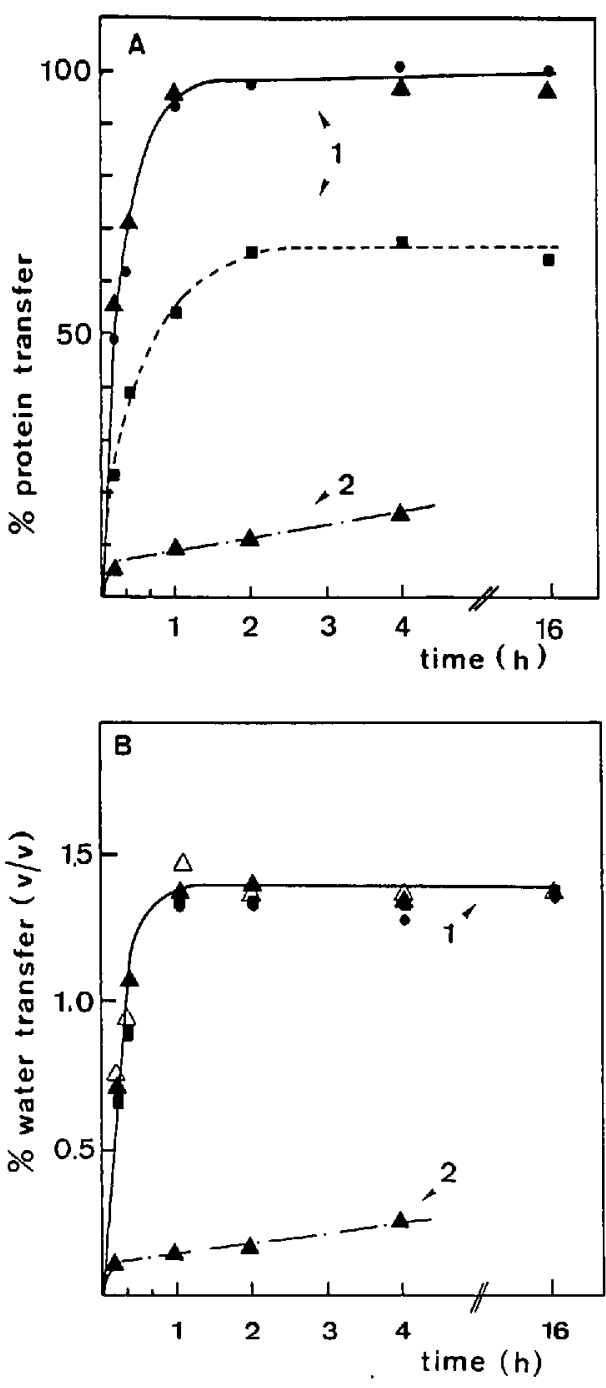

Fig. 1. A: Time progress of the solubilization of lysozyme (O), ribonuclease $A(\mathbf{\Delta})$, and trypsin (ם) into $50 \mathrm{~mm} A O T /$ isooctane using the liquid-liquid phase-transfer method. The volume of each of the two phases is $3 \mathrm{ml}$. The aqueous phase contains $0.1 \mathrm{M} \mathrm{CaCl}_{2}, 20 \mathrm{~mm}$ acetate buffer $\mathrm{pH} 5.0$. A $100 \%$ protein transfer corresponds to a protein concentration of $15 \mu \mathrm{M}$. The two upper curves $(1)$ are obtained with mild shaking (150 rpm) for $16 \mathrm{~h}$, the lower (2) one without shaking at all. B: Time progress of the simultaneously occuring $\mathrm{H}_{2} \mathrm{O}$ solubilization; same denominations as in Fig. 1, A. $\triangle: \mathrm{H}_{2} \mathrm{O}$ transfer without the presence of protein in the system.

identical, and quantitative after $c a .1$ h of extraction. The transfer of trypsin, however, reaches a lower plateau value after $c a$. 2 h. Recognizing that the molecular weights of lysozyme and ribonuclease are very similar $(14400 \mathrm{D}$ and $13700 \mathrm{D}$, respectively) and considerably smaller than that of trypsin $(23800 \mathrm{D})$, one could suggest that the size of the protein plays an important role in the transfer kinetics, since all three proteins have a basic pI, well above the $\mathrm{pH}$ used in the experiments. However, other parameters may also be significant, i.e. the hydrophobicity, the charge density of the protein, and possibly the specific interaction of the proteins with the surfactant molecules. We will discuss this point later.

Let us consider now Fig. $1 B$ which shows the extent of $\mathrm{H}_{2} \mathrm{O}$ being transferred into the supernatant organic phase accompanying the transfer of the proteins. The equilibrium is reached after $c a .1 \mathrm{~h}$, and only $1.4 \% \mathrm{H}_{2} \mathrm{O}$ (referred to the $3 \mathrm{ml}$ of initial $\mathrm{H}_{2} \mathrm{O}$ ) is transferred. This corresponds under our conditions ( $50 \mathrm{~mm}$ AOT) to a $w_{0}$ of ca. 16. Both the kinetics and the equilibrium values are not affected by the presence of the proteins. Note also that the shaking magnitude affects the transfer rate in a significant way. The percentage of transfer at equilibrium, however, is not changed. In the case of ribonuclease, for example, after $4 \mathrm{~h}$ equilibrating without shaking only $17 \%$ of the protein and $0.25 \%$ of the $\mathrm{H}_{2} \mathrm{O}$ was extracted into the micellar phase.

If one is not interested in obtaining precise kinetic data, it is possible to accelerate drastically the process of protein transfer. This is done by increasing the magnitude of shaking which can also be accomplished by simple mechanical mixing of the two phases. Then, the formed emulsion is allowed to separate. In this case, the maximal transfer (equilibrium value) of the proteins can be achieved within 5-30 min [5] [6] [58]. The time necessary for the complete transfer seems, however, to be also dependent on the type of the extracted proteins. Cytochrome c, for example, is solubilized faster than other proteins such as $\alpha$-chymotrypsin [58].

It has to be mentioned that the transfer from aqueous into micellar phases is generally completed in a shorter time than the back-transfer from the micellar into the aqueous solution. Göklen and Hatton [5] [6] showed that the forward transfer of cytochrome $c$ is completed already after 5 min, whereas its back-tranfer takes at least 15 min under the used experimental conditions. We have observed a smiliar behaviour extracting other proteins [29-31] [37].

A further observation stems from the inspection of Fig. 1: the fact of the moder- ate $\mathrm{H}_{2} \mathrm{O}$ transfer under conditions, in which a quantitative transfer of protein takes place, is rather surprising. This demonstrates, as already suggested by our first studies [28-31] that the extraction of proteins is not a passive process due to the $\mathrm{H}_{2} \mathrm{O}$ being transferred. In such a 'passive' case one would expect that only $1.5 \%$ of the total protein would be solubilized into the micellar solution. No concentration of protein with respect to the present micellar $\mathrm{H}_{2} \mathrm{O}$ content would be expected. Nevertheless, since the kinetics of the $\mathrm{H}_{2} \mathrm{O}$ and the protein transfer are independent on the shaking mode (i.e. with 150 RPM or without shaking a similar ratio of the transferred amount of $\mathrm{H}_{2} \mathrm{O}$ to protein is observed, see Table 2), it is assumed, however, that the protein and $\mathrm{H}_{2} \mathrm{O}$ transfer is related to each other. Every protein molecule is accompanied by a certain amount of $\mathrm{H}_{2} \mathrm{O}$ molecules which is certainly dependent on the properties both of the micelles and individual proteins. For ribonuclease A or lysozyme, ca. 50000 $\mathrm{H}_{2} \mathrm{O}$ molecules per enzyme molecule are extracted into the micellar phase, whereas in the case of the larger trypsin, $c a .80000$ $\mathrm{H}_{2} \mathrm{O}$ molecules per enzyme molecule are extracted simultaneously.

\subsubsection{Factors Affecting the Yield of \\ Protein Transfer}

In the experiments carried out until now the organic phases contained no initial $\mathrm{H}_{2} \mathrm{O}$. The question, how the transfer data change, if a certain amount of $\mathrm{H}_{2} \mathrm{O}$ is already present in the micellar solution, is shortly discussed in the following. Clearly, there should be no change in case of a thermodynamic equilibrium. Figs. $2 A$ and $2 B$ show the results. By changing the initial $w_{\mathrm{o}}$ in the range 0 to 30 , there is no difference of the transfer yield of trypsin, neither with aqueous $\mathrm{CaCl}_{2}$ nor $\mathrm{NaCl}$ solutions. Note also that the final micellar $\mathrm{H}_{2} \mathrm{O}$ content is as well not affected by the initial $w_{0}$. However, the absolute $w_{0}$ value is different for the two salts, namely 18 with $0.02 \mathrm{M}$ $\mathrm{CaCl}_{2}$, and 27 with $0.1 \mathrm{M} \mathrm{NaCl}$ at $4^{\circ}$.
Table 2. Ratio of Transferred Protein to $\mathrm{H}_{2} \mathrm{O}^{\mathrm{a}}$ ) as a Function of Time

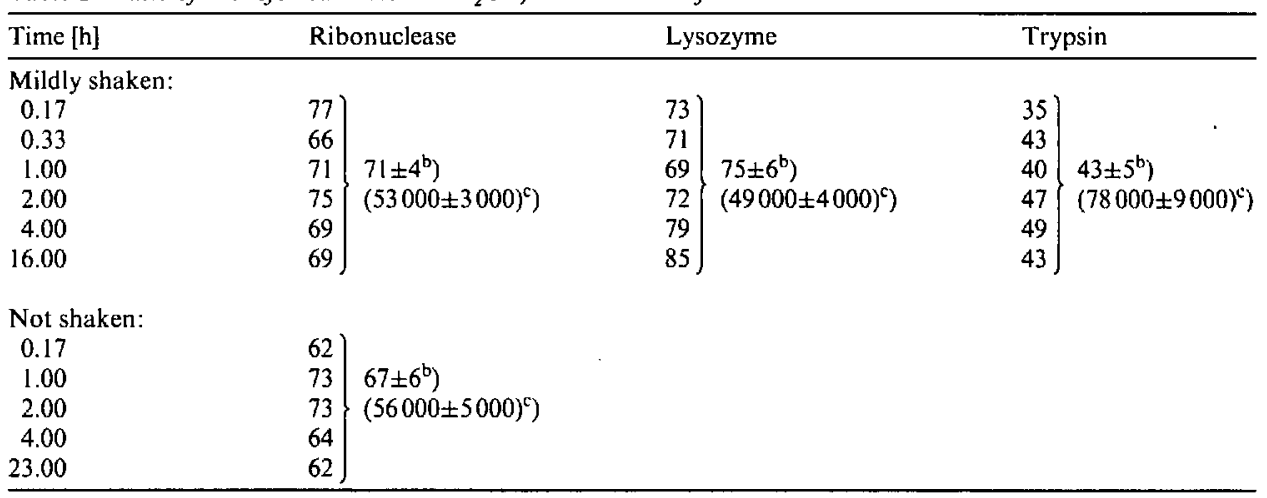

a) Ratio is given as: \% protein transfer to \% $\mathrm{H}_{2} \mathrm{O}$ transfer (same data taken from Fig. l)

b) Average transfer ratio.

c) Calculated number of $\mathrm{H}_{2} \mathrm{O}$ molecules transferred into the AOT microemulsion per transferred enzyme molecule. 

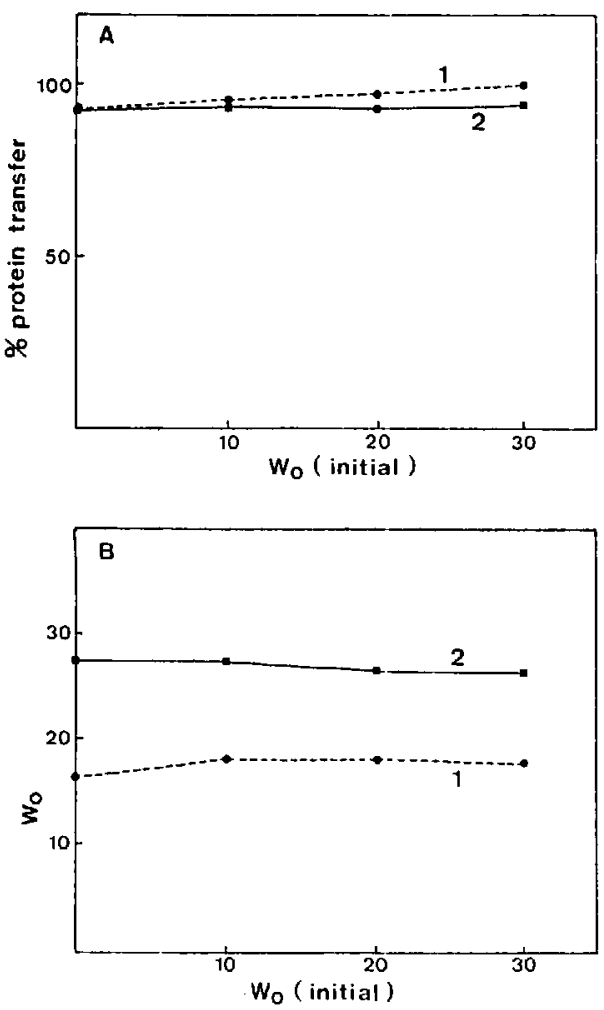

Fig. 2. A: Transfer efficiency of trypsin into $50 \mathrm{~mm}$ AOT/isooctane as a function of initial micellar $\mathrm{H}_{2} \mathrm{O}$ content ( $w_{\mathrm{o}}$ initial). The aqueous phase contained either $20 \mathrm{~mm}$ $\mathrm{CaCl}_{2}($ I) or $100 \mathrm{~mm} \mathrm{NaCl}$ (2). All experiments carried out at $4^{\circ}$ with $16 \mathrm{~h}$ of mild shaking (150 rpm). The different temperature accounts for the different transfer yield between these experiments and those carried out at room temperature. B: Partitioning of $\mathrm{H}_{2} \mathrm{O}$ between the two phases; same symbols as in Fig. 2, $A$.

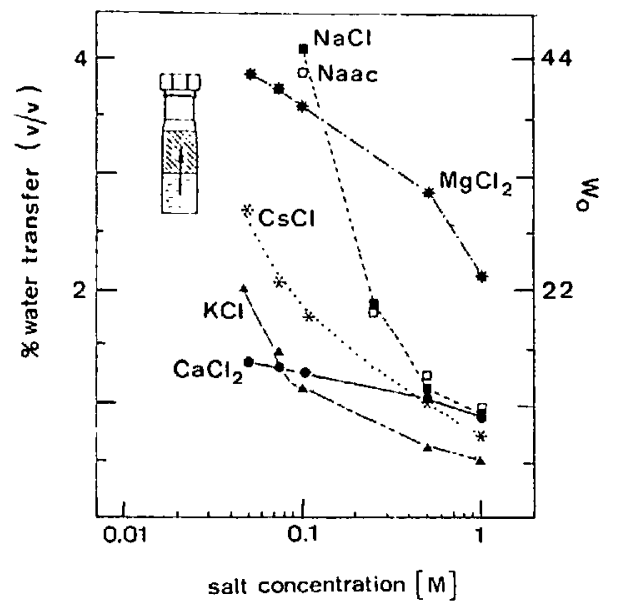

Fig. 3. Influence of salt (present in the aqueous phase) on the transfer of $\mathrm{H}_{2} \mathrm{O}$ into the micellar phase ( $50 \mathrm{~mm} \mathrm{AOT/isooctane).}$ The percentage of $\mathrm{H}_{2} \mathrm{O}$ transferred is given in volume- $\%(v / v)$ with respect to the total volume of the hydrocarbon phase (lefthand side $y$ axis); the right-hand side $y$ axis indicates the corresponding $w_{\mathrm{a}}$, assuming $50 \mathrm{~mm}$ AOT in the organic phase; $3 \mathrm{ml}$ of each phase; room temperature; mildly shaking (150 rpm) during $16 \mathrm{~h}$; Naac: sodium acetate. The insert shows the experimental configuration.
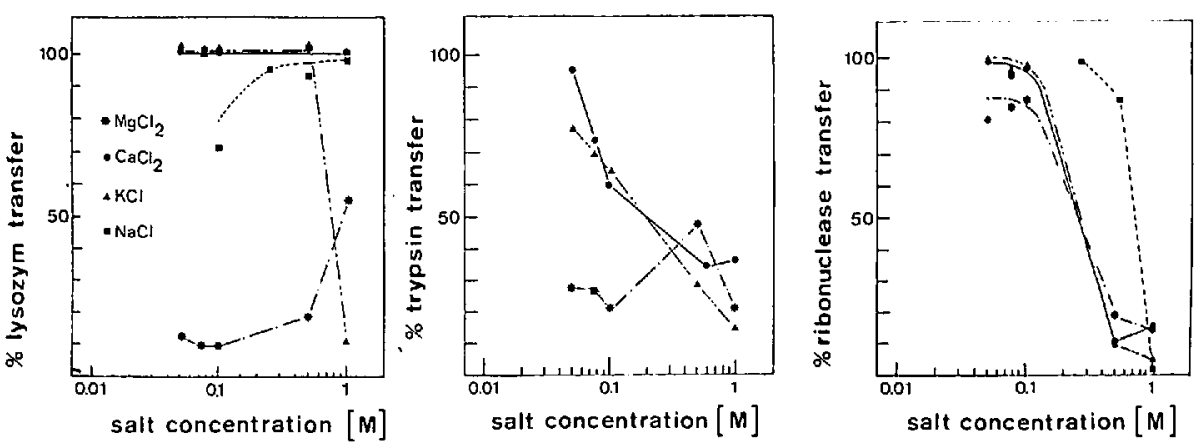

Fig. 4. Influence of salt on the transfer of lysozyme, ribonuclease $A$, and trypsin from several aqueous salt solutions (pH 5.0,20 mM NaOAc buffer) into a microemulsion phase $(50 \mathrm{~mm}$ AOT/isooctane). $100 \%$ transfer corresponds to $15 \mu \mathrm{M}$ protein in the micellar phase. $16 \mathrm{~h}$ mildly shaking (150 rpm); room temperature.

\subsubsection{Ionic Strength}

\section{Effect on $\mathrm{H}_{2} \mathrm{O}$ Transfer}

The effect of salt in the aqueous phase on the efficiency of $\mathrm{H}_{2} \mathrm{O}$ transfer in the absence of protein is presented in more detail in Fig. 3. Note that the transfer of $\mathrm{H}_{2} \mathrm{O}$ increases by decreasing the aqueous salt concentration, and that the type of salt affects specifically the final $\mathrm{H}_{2} \mathrm{O}$ content in the micellar solution. Assuming that the organic AOT concentration does not change significantly during the transfer experiment, as was showed recently [24], it is possible to calculate the droplet size after equilibration with different aqueous salt solutions using the relation: $r_{\mathrm{wp}}=1.75 \cdot w_{\mathrm{o}}$ (see Chapt. I.1). In a recent small-angle neutron-scattering study Sheu et al. measured droplet sizes after equilibrating the micellar phase with different $\mathrm{KCl}$ solutions. The determined radii agreed quite well with the calculated values [9]

The dependence of the equilibrium $\mathrm{H}_{2} \mathrm{O}$ solubilization on the used salt-type shows, however, no clear qualitative correlation with the well-known Hofmeister series [59]. Caselli and coworkers [21] examined this phenomenon in more details, looking as well at different salt types and concentrations. They found that not only $\mathrm{H}_{2} \mathrm{O}$ but also the cations are distributed between the two phases during extraction experiments. The extent of the distribution is thereby dependent on the aqueous salt concentration. Fletcher [17] reported a similar finding for the distribution of $\mathrm{NaCl}$ in the twophase AOT system. Leodidis and Hation published [10] recently a phenomenological electrostatic model which predicts the distribution of different cations between the two phases in the $\mathrm{AOT} / \mathrm{H}_{2} \mathrm{O} /$ isooctane system. Discrimination between different cations is assumed on the basis of charge, hydrated size, and electrostatic free energy of hydration.

\section{Effect on Protein Transfer}

The effect of salt on the efficiency of protein transfer is discussed next. An example is given in Fig. 4 which summarizes the transfer efficiencies of lysozyme, ribonuclease $A$, and trypsin in dependence of different salts and ionic strengths. The transfer yield changes abruptly within a very small salt concentration range. In the case of ribonuclease $\mathrm{A}$, for example, it increases from 0 to $100 \%$ changing the aqueous $\mathrm{NaCl}$ concentration from $\mathrm{IM}$ to $0.3 \mathrm{~m}$. Note also that different salts exhibit a different effect on the same protein: for example, in the case of lysozyme, the transfer is quantitative with $\mathrm{CaCl}_{2}$ and $\mathrm{NaCl}$, regardless of the investigated salt concentration range. With $\mathrm{MgCl}_{2}$ the transfer is, however, reduced, and actually in this case the transfer yield decreases by decreasing the salt concentration.

It could be shown that the presence of protein in the transfer system does not influence significantly the micellar $\mathrm{H}_{2} \mathrm{O}$ content at equilibrium. The measured $\mathrm{H}_{2} \mathrm{O}$ transfer efficiencies were the same as observed in the absence of protein [58].

The effect of ionic strength on the efficiency on the protein solubilization was also examined by other research groups. Göklen and Hatton [5] [6] examined the influence of the aqueous $\mathrm{KCl}$ concentration on the extraction efficiency of lysozyme, cytochrome $\mathrm{c}$, and ribonuclease A into $50 \mathrm{~mm}$ AOT/isooctane. They also found an increased solubilization of protein, when the aqueous salt concentration was decreased, and a different solubilization behaviour for the three considered proteins. Lysozyme could be extracted quantitatively already at a $\mathrm{KCl}$ concentration smaller than $0.5 \mathrm{M}$, whereas, for $\mathrm{cy}$ tochrome $c$, the maximal efficiency was reached at $c a .0 .2 \mathrm{M}$. Caselli and coworkers [21] obtained very similar results for the extraction of cytochrome $\mathrm{c}$ from $\mathrm{KCl}$ solutions. They also extended their systematic study on the elucidation of the influence of other salt types, such as $\mathrm{LiCl}$.

\subsubsection{Effect of $p H$}

Lysozyme, trypsin, and ribonuclease $A$ have a very high isoelectric point (11.0, 10.8 , and 9.5, respectively) and show, therefore, an overall positive charge under conditions where the aqueous $\mathrm{pH}$ is lower than their pI. Since all experiments of protein transfer discussed so far, have been 


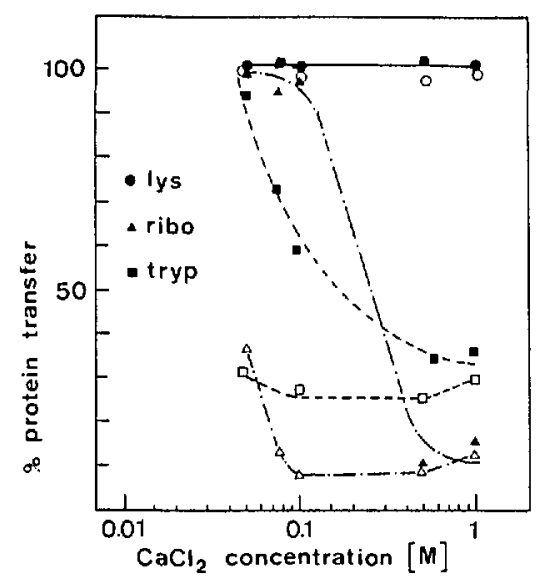

Fig. 5. Transfer yield of lysozyme (lys), ribonuclease $A$ (ribo), and trypsin (tryp) at $p H 5.0$ (full symbols; $20 \mathrm{~mm}$ acetate buffer) and $\mathrm{pH} 10.0$ (open symbols; $20 \mathrm{~mm}$ borate buffer) as a function of the aqueous $\mathrm{CaCl}_{2}$ concentrations. Same experimental conditions as before.

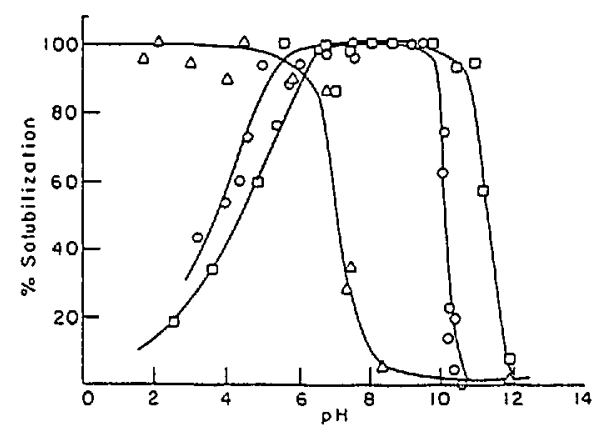

Fig. 6. Effect of $\mathrm{pH}$ on the solubilization of lysozyme $(\square)$, cytochrome $c(O)$, and $\mathrm{ri}$ bonuclease $A(\triangle)$ in $50 \mathrm{~mm} A O T /$ isooctane solutions; $0.1 \mathrm{M} \mathrm{KCl}$; from [6]

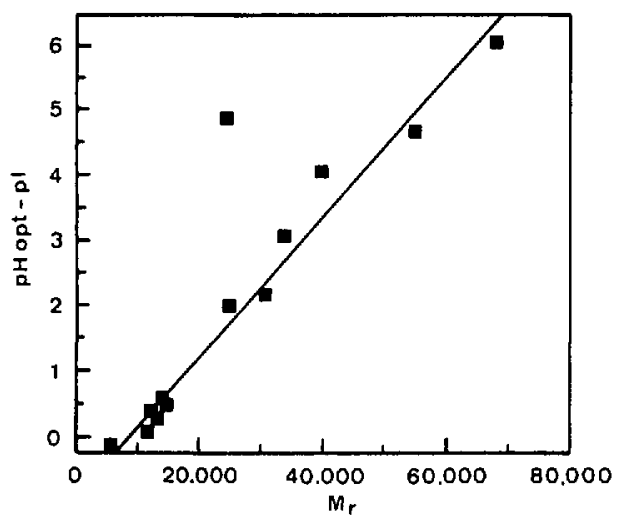

Fig. 7. Relation between the molecular weight of proteins and the difference between the protein's $p l$ and the $\mathrm{pH}$ of optimal extraction into a reversed micellar phase of TOMAC in isooctane/octanol; from [15]

carried out at $\mathrm{pH} 5$ (well below the pl's), it was interesting to study the transfer efficiency at a much higher aqueous $\mathrm{pH}$, i.e. at $\mathrm{pH} 10$, where the three proteins are neutral or much closer to neutrality. Results are shown in Fig.5. In spite of their similar pl's, it is apparent that the three proteins behave differently. In the case of lysozyme, there is no difference found in the transfer between the two $\mathrm{pH}$ 's, whereas ribonuclease or trypsin are much better extracted into the micellar phase at the lower $\mathrm{pH}$ value. These results indicate that electrostatic interactions of the protein with the AOT molecules determine to a certain extent the transfer into the micellar solution. The case of lysozyme is in this context, however, an exception.

Göklen and Hatton [6] studied the $\mathrm{pH}$ effect on the extraction efficiency into AOT micelles more systematically. The results of this investigation are summarized in Fig. 6 [6]. It shows the same general behaviour as described before. The basic proteins lysozyme, ribonuclease $\mathrm{A}$, and cytochrome $\mathrm{c}$ are all extracted quantitatively at an aqueous $\mathrm{pH}$ which is under their $\mathrm{pl}$ value. Moreover, these authors could show that the $\mathrm{pH}$ dependence is different for each protein and not understandable by simply comparing the different protein $\mathrm{pl}$ values.

\subsubsection{Effect of Surfactant Type (Anionic vs. Cationic)}

To have a better insight into the importance of electrostatic vs. hydrophobic forces in the phase-transfer process, we have compared the transfer efficiency of the three previously studied proteins with that of pepsin (has a low $\mathrm{pl}(1.0)$ ) into AOT and CTAB (cetyltrimetylammonium bromide) microemulsions. CTAB is a cationic surfactant. When working at $\mathrm{pH} \mathrm{5,} \mathrm{the}$ three proteins which are overwhelmingly positively charged at this $\mathrm{pH}$, should be extracted preferentially into the anionic AOT micelles, whereas pepsin is expected to be transferred better into the CTAB phase. Moreover, it is also interesting to see, whether the extent of $\mathrm{H}_{2} \mathrm{O}$ solubilization, accompanying protein extraction, is different in the two micellar systems. Results are shown in Table 3 . At pH 5 the three basic enzymes are essentially extracted into the AOT reverse micelles, whereas the acid pepsin is better transferred into the CTAB microemulsion. Note that the $\mathrm{H}_{2} \mathrm{O}$ content at equilibrium is different for the two micellar systems, but is not significantly influenced by the presence of the proteins.

The importance of electrostatic effects in the phase transfer from aqueous to micel- lar solutions is also mentioned by other groups. Hatton [11], for example, reported that the extraction efficiency of cytochrome cor ribonuclease $\mathrm{A}$ into a system of $50 \mathrm{~mm}$ DDAB (didodecyldimethylammonium bromide; a cationic surfactant) in trichloroethylene at an aqueous $\mathrm{pH}$ under their $\mathrm{pl}$ values is not very high. Increasing the aqueous $\mathrm{pH}$, the proteins were preferentially solubilized into the cationic surfactant system. Dekker and coworkers [12] published recently a systematic study which was focused on the extraction of $\alpha$-amylase (pl 5.2, $M_{\mathrm{r}} 48000 \mathrm{D}$ ) into microemulsions consisting of TOMAC/OCtanol $(=\operatorname{cosurfactant}) / \mathrm{H}_{2} \mathrm{O} /$ isooctane. The aqueous $\mathrm{pH}$ was also in this case an important parameter determining not only the forward extraction but also the backward extraction efficiency. At a $\mathrm{pH}$ of 9.9 , the $\alpha$-amylase (has mainly negative charges on its surface at this $\mathrm{pH}$ ) could be extracted in a high yield into the micellar phase, and, at a $\mathrm{pH}$ close to the protein $\mathrm{pl}$ value, it was stripped back almost quantitatively into the aqueous phase. In a further investigation, the same group determined the influence of intrinsic protein properties on their partitioning behaviour [15]. The distribution characteristics of different proteins were influenced not only by their isoelectric point, but also by their size. Fig. 7 [15] shows the relation between the molecular weight of the solubilized protein and the difference between the proteins's pl and the $\mathrm{pH}$ of optimal extraction into a TOMAC reversed micellar phase. The bigger the protein, the bigger is the difference $\left(\mathrm{pH}_{\mathrm{op}}-\mathrm{pl}\right)$. This protein-size effect seems moreover not to be restricted to the investigated TOMAC system but also valuable for anionic AOT systems [15]. Whereas in the cationic TOMAC system the optimal $\mathrm{pH}$ for extraction is always higher than the protein pI, it lays below the pl in the anionic AOT system.

Another interesting finding concerns the protein extraction efficiency in relation to the protein surface charge distribution [15]. The same authors found that proteins having an asymmetric charge distribution on their surface are more easily transferred into the TOMAC system than proteins having a symmetric charge distribution. Lysozyme, for example, which has a very symmetric charge distribution, could not be transferred in a significant amount, whereas ribonuclease $A$ or cytochrome $c$.

Table 3. Extraction Yield of Different Enzymes

\begin{tabular}{|c|c|c|c|c|}
\hline \multirow[t]{3}{*}{ Enzyme (pl) } & \multicolumn{4}{|c|}{ Yield of transfer $[\%]^{a}$ ) } \\
\hline & \multicolumn{2}{|c|}{ into $\mathrm{CTAB}$ micelles } & \multicolumn{2}{|c|}{ into AOT micelles } \\
\hline & Enzyme & $\mathrm{H}_{2} \mathrm{O}$ & Enzyme & $\mathrm{H}_{2} \mathrm{O}$ \\
\hline Lysozyme (11.0) & 0 & 2.8 & 102 & 1.2 \\
\hline Ribonuclease $(9.5)$ & 4.7 & 2.5 & 97.0 & 1.3 \\
\hline Trypsin (10.8) & 2.4 & 2.4 & 95.3 & 1.3 \\
\hline Pepsin (1.0) & 49.0 & 2.6 & 9.0 & 1.4 \\
\hline
\end{tabular}

a) The enzyme transfer is referred to the protein initial amount present in the aqueous phase ( $15 \mu \mathrm{M})$; the $\mathrm{H}_{2} \mathrm{O}$ transfer is referred to the initial volume $(3 \mathrm{ml})$ of the aqueous phase $(\mathrm{pH} 5$ with $20 \mathrm{~mm} \mathrm{NaOAc}$ and $50 \mathrm{~mm}$ $\mathrm{CaCl}_{2}$ ). The organic phase consists of $50 \mathrm{mM}$ AOT/isooctane or of $50 \mathrm{~mm}$ CTA B isooctanc/hexanol $1: 1(v / v)$; mildly shaken $(150 \mathrm{rpm})$ for $16 \mathrm{~h}$; room temperature. 

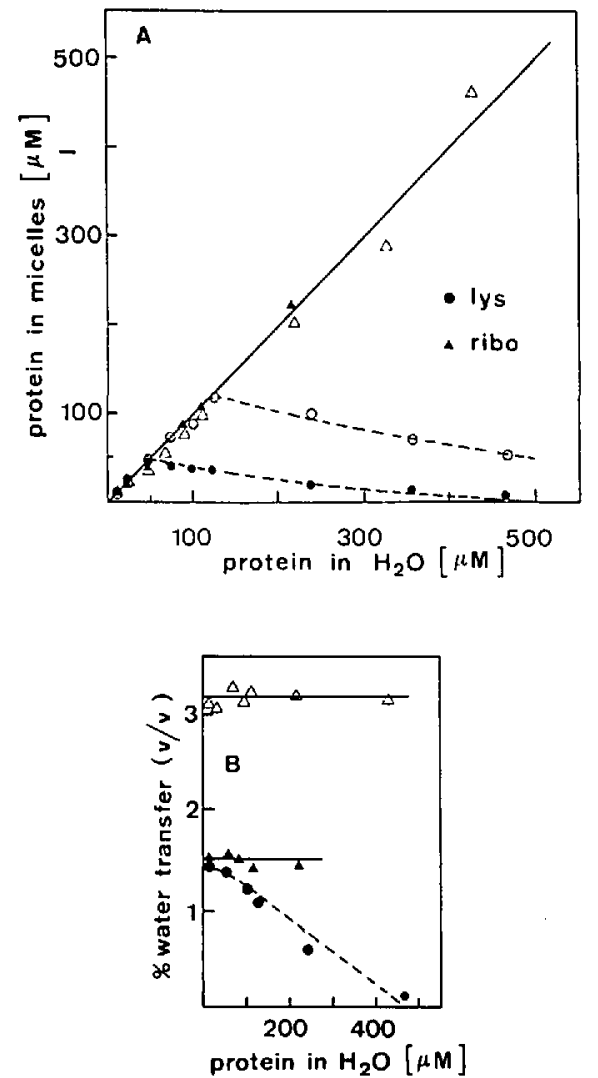

Fig. 8. A: Transfer of Ribonuclease A (ribo) and lysozyme (lys) into $50 \mathrm{~mm}$ (full symbols) and $100 \mathrm{~mm}$ (open symbols) $A O T /$ isooctane solutions as a function of initial protein concentration in the aqueous phase $\left(0.1 \mathrm{M} \mathrm{CaCl}_{2}, 20 \mathrm{~mm} \mathrm{NaOAc}\right.$ buffer $\left.\mathrm{pH} 5\right)$. Room temperature, $150 \mathrm{rpm}$; $16 \mathrm{~h}$; overall concentrations. B: Simultaneously occurring $\mathrm{H}_{2} \mathrm{O}$ transfer. Same symbols as in Fig. $8, A$

which both have a more pronounced asymmetric charge distribution, were extracted in a much better yield at the optimal aqueous $\mathrm{pH}$.

\subsubsection{Effect of Aqueous Protein \\ Concentration}

Another parameter influencing the distribution process is the protein concentration initially given in the aqueous phase. So far the aqueous protein concentration did not exceed $0.4 \mathrm{mg} / \mathrm{ml}$ protein $(\sim 20 \mu \mathrm{M})$. Results for lysozyme and ribonuclease $A$ are shown in Fig. 8 which also shows the extent of the accompanied $\mathrm{H}_{2} \mathrm{O}$ extraction in to the micellar phase. The chosen salt concentration corresponds to a case which gave maximal extraction, when using a total initial protein concentration of $15 \mu \mathrm{M}$ (see Fig. 4). The aim was to see, at which initial aqueous protein concentration the micellar phase is saturated with protein. Again, results are different for the two proteins. While ribonuclease is transferred quantitatively up to an aqueous concentration of ca. $220 \mu \mathrm{M}$ into $50 \mathrm{mM}$ AOT/isooctane and up to $450 \mu \mathrm{m}$ into $100 \mathrm{~mm}$ AOT/ isooctane, i.e. twice as much, lysozyme extraction decreases with increasing aqueous enzyme concentration. Fig. $8 B$ shows that this effect is accompanied by a decrease of the measured micellar $\mathrm{H}_{2} \mathrm{O}$ content. The reason for this difference is not clear, but is most likely connected with specific properties of the protein surface. Favorable hydrophobic interactions between the protein and the AOT molecules might play a significant role in the extraction of lysozyme. The formation of a new phase which is probably rich in surfactant, lysozyme, and water is observed. Notice that lysozyme showed also a peculiar behaviour in the experiments described before.

The increased protein uptake into a micellar phase with increased surfactant concentration was also reported by Fletcher and Parrot [18]. They were looking at the extraction behaviour of $\alpha$-chymotrypsin into the system AOT/heptane.

\subsection{Transfer of Amino Acids}

Since the importance of electrostatic effects in the liquid-liquid phase transfer is expected to be more discernible with small peptides, we describe in the following section a few of our own recent experiments using some tyrosine and tryptophan derivatives. We report the transfer efficiency into an anionic and a cationic microemulsion system. The attention in these experiments stems also from the obvious biotechnological interest that separation of peptides and amino-acids offers per se. We studied not only the electrostatic factors which we will, however, concentrate on in the following, but also hydrophobic effects. Especially the group at M.I.T. investigated the influence of hydrophobicity of amino acids in more detail [7].

The electrostatic effect is examined by comparing the extraction behaviour of different amino acids into a CTAB and an AOT surfactant system. The obtained results are summarized in Table 4. It is clearly shown, that the positively charged compounds are overwhelmingly extracted into the anionic AOT micelles, whereas the reverse observation is true for the negatively charged ones. This was to be ex-

Table 4. Comparison of the Phase Transfer of Some Amino Acids into CTAB and AOT Microemulsions

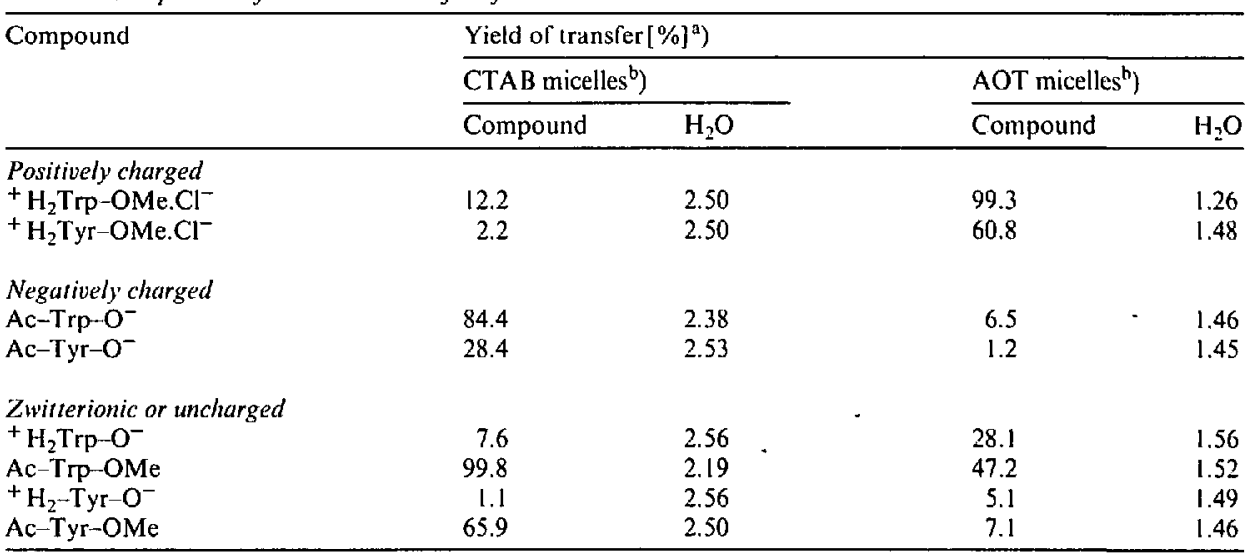

a) $100 \%$ transfer corresponds to an overall micellar concentration of $4.2 \mathrm{~mm}$ for all compounds except for AC-Trp-OMe and ${ }^{+} \mathrm{H}_{2}$ Tyr- $\mathrm{O}^{-}$(2.1 mM; poorer solubility in aqueous solutions). All amino acids have the L-configuration.

b) $50 \mathrm{~mm}$ CTAB in isooctane/hexanol $1: 1(v / v)$ and $50 \mathrm{~mm}$ AOT in isooctane. The aqueous phase contains $50 \mathrm{~mm}$ $\mathrm{CaCl}_{2}$ in $20 \mathrm{~mm} \mathrm{NaOAc} \mathrm{pH}$. The volume of both the $\mathrm{H}_{2} \mathrm{O}$ and the organic phase was $3 \mathrm{ml}$; room temperature mildly shaken (150 rpm) for $16 \mathrm{~h}$ pected on the basis of electrostatic interactions. However, the percentage of transfer is different for the different compounds, and it is, even for these much smaller compounds compared with the size of proteins, not easy to find a satisfactory explanation. It appears, that electrostatic interactions are not the only factors determining the phase transfer. This especially arises from thaveur of uncharged or zwitterionic compounds, whose hydrophobic interacwith the surfactant molecules appear to play an important role when transferred the microemulsion system.

The transfer of $\mathrm{H}_{2} \mathrm{O}$ is again not much affected by the presence of the amino acids. However, it is different for the two micromulsion systems, ranging between 1.2 and $1.6 \%$ in the case of the AOT, and between 2.2 and $2.6 \%$ in the case of the CTAB system. Same corresponding $\mathrm{H}_{2} \mathrm{O}$ values were also measured after the extraction of proteins.

The importance of electrostatic effects in the determination of the phase-transfer efficiency of charged amino acids was also tested in a three-phase system, in which the aqueous phase was sandwiched between a $\mathrm{AB}$ and an AOT microemulsion phase [34]. In this system, the aqueous phase $(\mathrm{pH}$ 5) contained initially $0.6 \mathrm{mM}$ of both a positively charged $\left({ }^{+} \mathrm{H}_{2}-\mathrm{Phe}-\mathrm{OMe}\right)$ and a negatively charged (Ac-Trp-O- ${ }^{-}$) amino-acid derivative. The positively charged compound was basically extracted into the anionic AOT microemulsion, whereas the negatively charged compound was only transferred into the cationic CTAB system.

\section{Extraction from the Solid State \\ 4.1. Extraction of Amino-Acid Derivatives and Small Peptides}

1.1. The Case of Hydrophilic Compounds powder of the compounds of interest usually into $50 \mathrm{~mm} \mathrm{AOT} / \mathrm{H}_{2} \mathrm{O} /$ isooctane solu- 


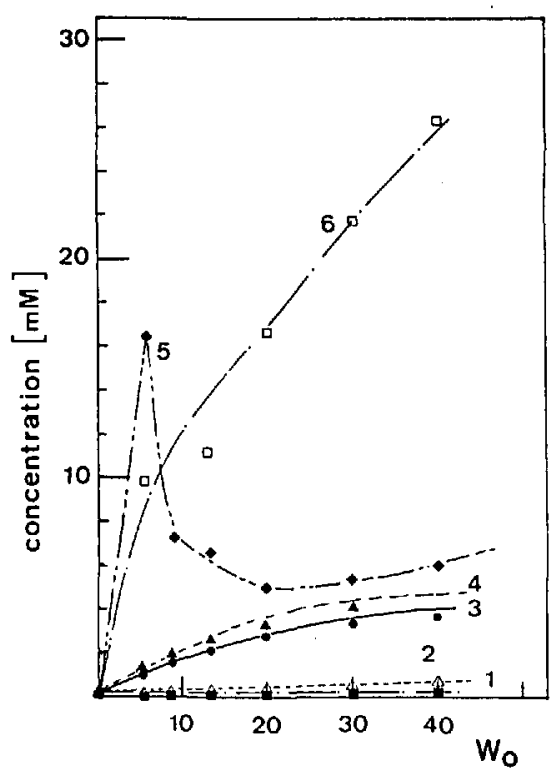

Fig. 9. Extraction efficiency of hydrophilic amino-acid derivatives from the solid state as a function of $\mathrm{w}_{0}(50 \mathrm{~mm}$ AOT/isooctane/ $\mathrm{H}_{2} \mathrm{O}$ ) I) $\mathrm{H}-\mathrm{Tyr}-\mathrm{OH}$; 2) Ac-Tyr-OMe; 3) racemic $\mathrm{H}-\mathrm{Trp}-\mathrm{OH}$; 4) Ac-Trp-OH; 5 ) HTyr-Tyr- $\mathrm{NH}_{2} \cdot \mathrm{HCl}$; 6) $\mathrm{H}-\mathrm{Tyr}-\mathrm{OH} \cdot \mathrm{HCl}$.

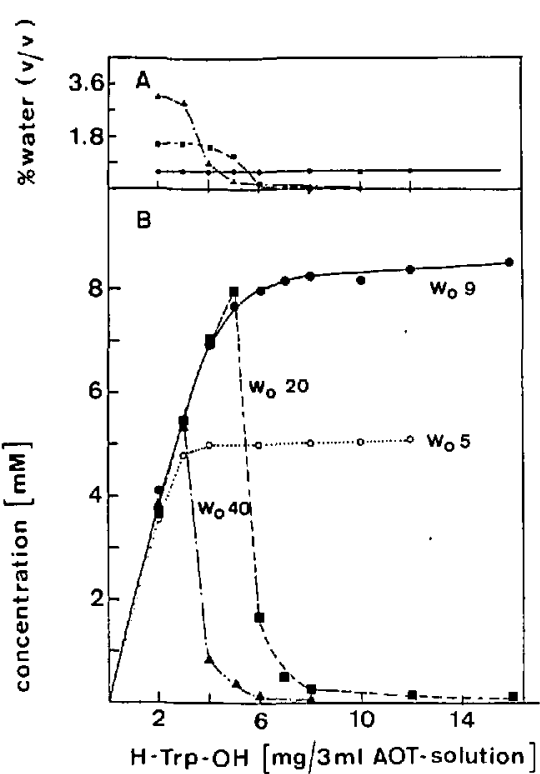

Fig. 10: A: $\mathrm{H}_{2} \mathrm{O}$ Amount measured in the micellar solution after the extraction of $\mathrm{L}$ tryptophan. Symbols defined in Fig. 10, B. B: Extraction of L-tryptophan suspended into $50 \mathrm{~mm} A O T /$ isooctane with different $\mathrm{w}_{\mathrm{o}}$ values as a function of the initial suspended amount of powder.

tions displaying different $w_{0}$ values. Unless otherwise specified, the $w_{0}$ was adjusted with distilled $\mathrm{H}_{2} \mathrm{O}$ (no buffer). The given amount of the powder was always in slight excess, i.e. a minimal amount of material was left unextracted. It was found that in some particular cases the powder of the amino-acid derivatives absorbed $\mathrm{H}_{2} \mathrm{O}$ from the micellar solution. The $\mathrm{H}_{2} \mathrm{O}$ amount in the micellar solution decreased during the extraction process. This effect is not simply due to the hygroscopicity of the material (in fact, 'wet' powders of the same com- pounds display a similar behaviour), but due to thermodynamic factors (formation of a new phase equilibrium). Same observations were made in the liquid-liquid phase transfer of lysozyme, when starting with a high initial aqueous enzyme concentration (see Chapt. 3.1.2.4). We will discuss this point later in more detail.

Typical results of the extraction of $\mathrm{H}_{2} \mathrm{O}$ soluble amino-acid derivatives are shown in Fig.9. These compounds are among those which do not change appreciably the initial $w_{\mathrm{o}}$ value of the micellar solution. It is obvious that generally more material is solubilized by increasing the $\mathrm{H}_{2} \mathrm{O}$ content of the micellar solution. However, the extraction behaviour is unique for each component. Note, for example, the difference between tyrosine and tryptophan and the close similarity between tyrosine and acetyltyrosine methyl ester, i.e. between a zwitterionic and an uncharged compound.

A peculiar behaviour was observed for $\mathrm{H}$-Tyr-Tyr- $\mathrm{NH}_{2} \cdot \mathrm{HCl}$; an extraction peak is obtained at $w_{0}$ of $c a$. 5. As we will see in Chapt. 4.2.1, a similar behaviour is determined for several small hydrophylic proteins.

Amino acids in the solid state are generally present in their zwitterionic form. Therefore, one would expect that a change of the ionization state of the amino acids in their powder form would affect the extraction behaviour. To check this point, we have performed an experiment which is summarized in Curve 6 of Fig.9. The tyrosine powder, used for this experiment, has been obtained by lyophilizing an aqueous tyrosine solution which has been first acidified with a few drops of $\mathrm{HCl}$ (see Experimental). Using this starting material the extraction behaviour is dramatically changed: much more material (by a factor of $c a .170$ ) is extracted, most likely because of the better electrostatic interaction with the negatively charged surfactant wall (tyrosine is present mainly in its positively charged form). In the extraction of the tyrosine in its zwitterionic form (see Curve I in Fig.9) these electrostatic effects appear to be negligible. They do not lead to high micellar concentrations.

Experiments with tryptophan, shown in Fig. 9, have been carried out with a racemic mixture. It could be demonstrated that the pure L- or D-form behaves differently compared to the racemate. This is not surprising in view of the fact that the solubility behaviour of racemic mixtures in pure $\mathrm{H}_{2} \mathrm{O}$ differs from that of the pure enantiomeric forms [60]. In fact, L-Trp belongs to the class of compounds whose powder absorbs a significant amount of $\mathrm{H}_{2} \mathrm{O}$ from the micellar solution. Typical data, obtained for this type of components, are shown in Fig. 10B; Fig. 10A shows the corresponding changes in the $w_{\mathrm{o}}$ values. The most important features of the complex behaviour shown in Fig. 10 can be summarized as follows: at a low suspended amount of material, the compound is solubilized quantitatively and linear, when more tryptophan is added. In the region up to $w_{0}=9$, under our conditions, a plateau is reached which is the higher, the higher is $w_{0}$. In the higher $w_{\mathrm{o}}$ region $(20-40)$, the solubilization degree drops sharply with increasing the suspended tryptophan amount. It is actually much lower than at $w=5$ or 9 . This behaviour can be related to changes in the $\mathrm{H}_{2} \mathrm{O}$ content of the micellar solution, as is shown in Fig. 10A. Starting, for example with $w_{0}=9$, the $\mathrm{H}_{2} \mathrm{O}$ content is not changed, when the suspended amount of powder is increased. On the contrary, starting with $w_{\mathrm{o}}=40$, the $\mathrm{H}_{2} \mathrm{O}$ content of the micellar solution decreases sharply after an initial linear region. The reason for the decreasing micellar $\mathrm{H}_{2} \mathrm{O}$ content, when the tryptophan powder is suspended in it, is probably due to dramatic changes in the thermodynamics of phase equilibria. It seems that the extent of the monophasic $\mathrm{L}_{2}$ region in the $A O T / \mathrm{H}_{2} \mathrm{O} /$ isooctane phase diagram is significantly affected by the addition of L-tryptophan. Further investigations dealing with the influence of this compound on the phase behaviour are needed to understand this phenomenon in more detail.

\subsubsection{The Case of More Hydrophobic Peptides}

Let us consider now the case of some peptides whose $\mathrm{H}_{2} \mathrm{O}$ solubility is reduced. because of the existence of a hydrophobic protecting group at the amino end. These compounds do not alter significantly the starting $w_{\mathrm{o}}$ value during the extraction process. Data are shown in Fig. 11 . The solubilization behaviour of most of the studied compounds is not influenced, when the micellar $\mathrm{H}_{2} \mathrm{O}$ content is varied. This means

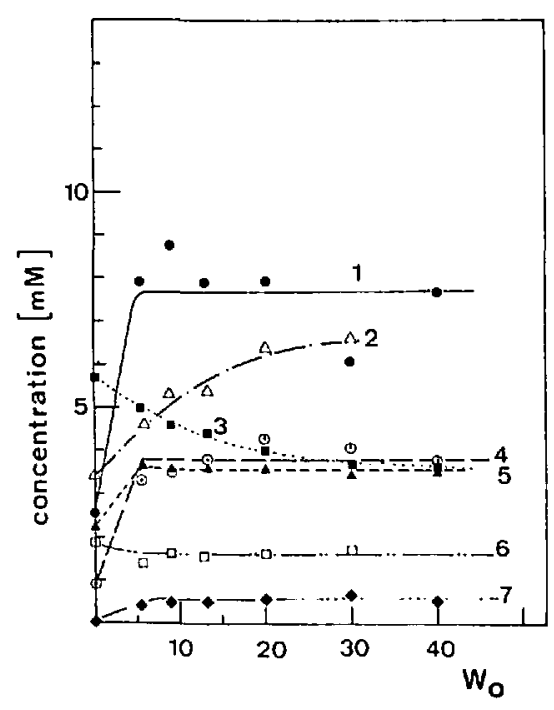

Fig. 11. Extraction of peptides, having a hydrophobic protecting group, into $50 \mathrm{~mm}$ $A O T /$ isooctane as a function of the micellar $\mathrm{H}_{2} \mathrm{O}$ content $\left(w_{\mathrm{o}}\right)$. 1) Boc-Trp-OH; 2) ZTyr-OH; 3) Boc-O-Benzyl-Tyr-OH; 4) Boc-Tyr-OH; 5) Z-Trp-OH; 6) Z-AlaPhe-OMe; 7) Z-Gly-Phe-Trp-OH. Z and Boc stand for the protecting groups (benzyloxy)carbonyl and (tert-butyloxy)carbonyl, respectively. 
Table 5. Maximal Solubility of Some Peptides in $\mathrm{H}_{2} \mathrm{O}$ and in $50 \mathrm{~mm}$ AOT/Isooctane Reverse Micelles

\begin{tabular}{|c|c|c|c|c|}
\hline \multirow[t]{3}{*}{ Peptide } & \multirow[t]{3}{*}{$\left.S_{w^{\prime}}{ }^{\mathbf{a}}\right)$} & \multicolumn{3}{|c|}{ Maximal solubility [mM] } \\
\hline & & \multirow[t]{2}{*}{ in $\mathrm{H}_{2} \mathrm{O}$} & \multicolumn{2}{|l|}{ in micelles } \\
\hline & & & $\left(w_{\alpha}\right)^{b}$ & at $w_{\mathrm{o}}=0$ \\
\hline $\begin{array}{l}\text { H-Trp-OMe- } \mathrm{HCL}^{\mathrm{C}} \text { ) } \\
\text { H-Trp-OH } \mathrm{OH}^{\mathrm{c}} \text { ) } \\
\text { rac-H-Trp-OH } \\
\text { Ac-Trp-OH } \\
\text { Ac-Trp-OMe }{ }^{\mathrm{c}} \text { ) } \\
\text { Boc-Trp-OH } \\
\text { Z Trp OH }\end{array}$ & $\begin{array}{l}36.8 \\
7.8 \\
4.3 \\
2.2 \\
1.2 \\
0.14 \\
0.07\end{array}$ & $\begin{array}{c}724 \\
64.1 \\
16.0 \\
8.2 \\
2.4 \\
1.1 \\
0.26\end{array}$ & $\begin{aligned} 19.7 & (5.4) \\
8.2 & (8.8) \\
3.7 & (40) \\
3.7 & (30) \\
2.0 & (40) \\
7.7 & (40) \\
3.5 & (40)\end{aligned}$ & $\begin{array}{l}0.95 \\
0.00 \\
0.01 \\
0.20 \\
0.20 \\
2.56 \\
2.18\end{array}$ \\
\hline 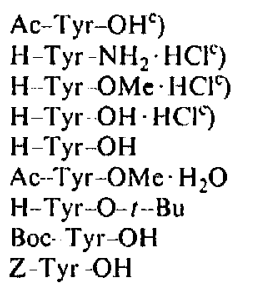 & $\begin{array}{c}58.7 \\
23.9 \\
17.9 \\
0.33 \\
13.0 \\
7.9 \\
1.06 \\
1.03 \\
0.69\end{array}$ & $\begin{array}{l}434 \\
311 \\
370 \\
8.8 \\
2.0 \\
4.5 \\
2.5 \\
4.2 \\
4.6\end{array}$ & $\begin{array}{l}7.4(8.8) \\
13.0(20) \\
20.7(30) \\
26.3(40) \\
0.15(40) \\
0.57(40) \\
2.4(40) \\
4.1(40) \\
6.6(30)\end{array}$ & $\begin{array}{l}0.40 \\
0.0 \\
2.03 \\
0.1 \\
0.0 \\
0.04 \\
0.54 \\
0.89 \\
3.40\end{array}$ \\
\hline $\begin{array}{l}\left.\mathrm{H}-\mathrm{Trp}-\mathrm{Trp}-\mathrm{OH}^{\mathrm{c}}\right) \\
\mathrm{H} \text { Tyr Tyr- } \mathrm{NH}_{2} \cdot \mathrm{HCl} \\
\text { Z Gly Phe-Trp-OH }\end{array}$ & $\begin{array}{l}3.5 \\
1.05 \\
0.10\end{array}$ & $\begin{array}{c}23.8 \\
19.7 \\
0.05\end{array}$ & $\begin{array}{c}6.8(5.4) \\
18.8(5.4) \\
0.52(40)\end{array}$ & $\begin{array}{l}0.03 \\
0.0 \\
0.04\end{array}$ \\
\hline
\end{tabular}

a) Molar ratio of maximal solubility in $\mathrm{H}_{2} \mathrm{O}$ to AOT micelles.

b) Initial $w_{0}$ value, at which the highest solubilization efficiency was found.

c) Compounds which decrease significantly the initial $w_{0}$ value (see text).

that the $w_{0}$ value does not influence the extraction yield of these peptides. Note that they have all an amphiphilic structure. The height of the plateau is, however, different for all compounds which is due to differences in the intrinsic properties of the peptide molecules. All these observations suggest that hydrophobic interactions between these peptides and the AOT molecules play an important role in the solubilization mechanism. The compounds may act as co-surfactants, and, therefore, they are expected to be mainly located in the AOT surfactant shell. The fact that the maximal solubilization of these peptides into $200 \mathrm{~mm} \mathrm{AOT} / \mathrm{H}_{2} \mathrm{O} /$ isooctane is ca. 4 times higher than in $50 \mathrm{~mm} \mathrm{AOT/isooctane}$ is in this respect not unexpected and supports also the picture of the AOT layer being the main solubilization location for these hydrophobic peptides (data not shown).

Most of the results obtained in the extraction experiments have been summarized in Table 5. Solubility data into micellar solutions at the optimal $w_{\mathrm{o}}$ as well as the solubility at $w_{0}=0$ (no water pools present) are given in 'overall' concentrations, i.e. relative to the total volume of $\mathrm{H}_{2} \mathrm{O}$ and organic solvent. As a comparison, we determined also the maximal solubility in $\mathrm{H}_{2} \mathrm{O}$. The arbitrarily defined coefficient $S_{\mathrm{w}}$ represents the molar ratio between the maximal solubility in $\mathrm{H}_{2} \mathrm{O}$ to the maximal solubility in AOT micelles at the optimal $w_{0}$ (these values are measured independently; $S_{\mathrm{w}}$ is not a partition coefficient). $S_{\mathrm{w}}$ is a useful parameter to compare solubilization behaviours of aqueous with micellar organic phases. Together with the solubility value at $w_{\mathrm{o}}=0$ (abbreviated as $\left.c_{w_{0}=0}\right)$, it is possible to characterize the solubilization behaviour of different components more quantitatively. We can distinguish between three 'solubilization modes': peptides having a small $S_{w}$ and a high $c_{\mathrm{w}_{0}=0}$ (i.e. Z-Trp-OH) show typical properties of co-surfactants (hydrophobic interactions with the micellar wall are dominant), whereas components exhibiting a high $S_{\mathrm{w}}$ and a small $c_{w_{0}=0}$ (i.e. H-Tyr$\mathrm{NH}_{2} \cdot \mathrm{HCl}$ ) are expected to be solubilized essentially by the water pool of the reverse micelles. Electrostatic interactions with the AOT head groups, however, can not be neglected. This is especially true for components which seem to alter significantly the phase behaviour of the AOT/ $\mathrm{H}_{2} \mathrm{O} /$ oil micoemulsion system which is evidenced by a decrease in the $w_{0}$ value. Components showing both a high $S_{w}$ and $c_{w_{0}=0}$ (i.e. $\mathrm{H}$ Trp-OMe $\cdot \mathrm{HCl}$ ) exhibit both hydrophilic and hydrophobic interactions with the AOT aggregates.

\subsection{Extraction of Proteins}

In the following section, we will consider the case of a few monomeric proteins (most of which belonging to the class of hydrolases), such as lysozyme, ribonuclease A, trypsin, $\alpha$-chymotrypsin, pepsin, papain, cytochrome $\mathrm{c}$, and bovine serum albumin (BSA). We will compare the obtained extraction data with some physical properties of these proteins (molecular weight, isoelectric point, charge and charge density; see Table I).

\subsubsection{The Case of Lysozyme, Ribonuclease $A$, and Cytochrome $c$}

First, we describe the extraction behaviour of the three smallest proteins, namely cytochrome $\mathrm{c}$, lysozyme, and ribonuclease A. It is summarized in Fig. 12 . In all three cases, the solubilization is characterized by an extraction peak at $w_{0}=8-12$. The maximal solubility in $50 \mathrm{~mm}$ AOT $/ \mathrm{H}_{2} \mathrm{O} /$ isooctane of these proteins is around $0.3 \mathrm{~mm}$ overall. Assuming that all protein is dissolved only in the water pool, the estimated micellar concentration (lo- cal) is about $30 \mathrm{~mm}$ which corresponds to ca. $400 \mathrm{mg} / \mathrm{ml}$ enzyme in the water pool. Such enzyme concentrations are in principle also possible in aqueous solutions (see e.g. for lysozyme [61]). These concentrated aqueous enzyme solutions are, however, very viscous and gel-like. The viscosity of the micellar solutions, containing the maximal amount of protein, corresponds instead practically to that of the pure solvent.

Peculiar solubilization curves of hydrophilic proteins into AOT reverse micelles were mentioned shortly also by Levashov and coworkers (lysozyme) [38], Grandi et al. (lysozyme) [32], and Nicot et al. (myelin basic protein $M_{r} 18500 \mathrm{D}$ ) [40]. Waks and his coworkers were in fact also able to solubilize a $\mathrm{H}_{2} \mathrm{O}$-insoluble protein, the Folch-Pi proteolipid $\left(M_{\mathrm{r}} 30,000 \mathrm{D}\right)$, using AOT in isooctane [41]. This protein surprisingly showed also a peak at low $w_{0}$ (around 5.5). Fig. 13 [40] [41] summarizes the solubilization behaviour of these two proteins which constitute together $c a .80 \%$ of the total protein in the multilamellar myelin sheath of the central nervous system.

To understand this peculiar extraction behaviour, we made recently the proposal [33], that the behaviour of Fig. 12 can be interpreted on the basis of two competitive solubilization modes: a so-called 'micellar(-wall) solubilization' mode and a 'water-pool solubilization' mode. The term 'micellar(-wall) solubilization' describes a mechanism, in which the species, mostly responsible for the solubilization, is the micellar wall. This mechanism is mainly due to interactions between the surfactant wall and the protein surface. As $w_{\circ}$ increases, the micelle becomes too large for this direct

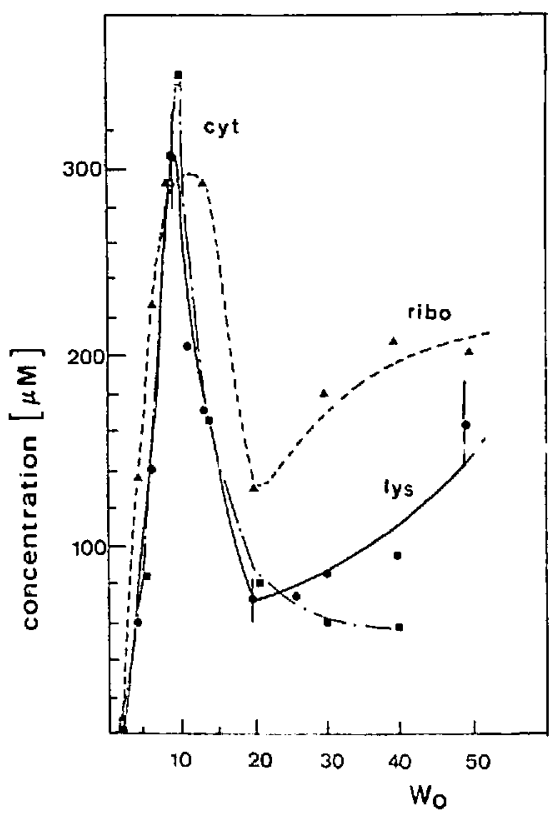

Fig. 12. Extraction of cytochrome $c$ (cyt), lysozyme (lys), and ribonuclease $A$ (ribo) into $50 \mathrm{~mm} A O T /$ isooctane as a function of the initial micellar $H, O$ content $\left(w_{0}\right)$; overall concentrations 

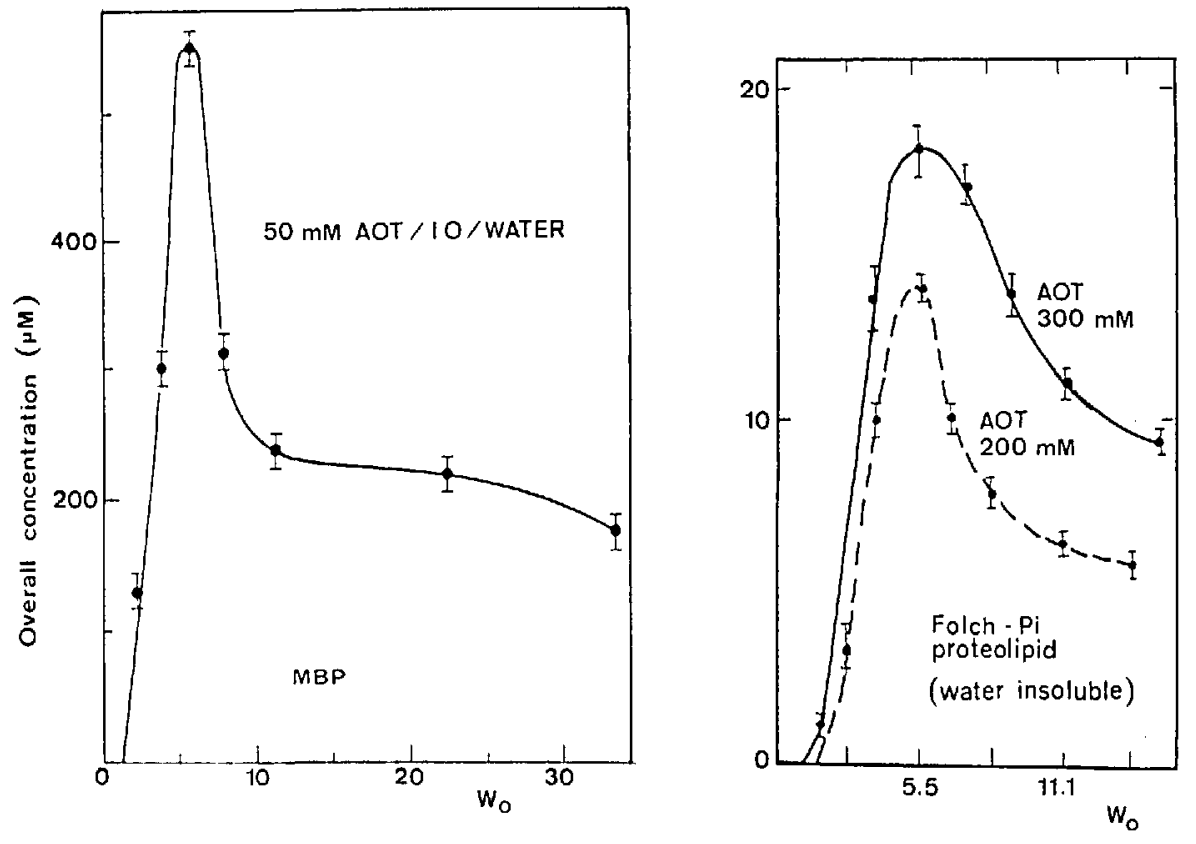

Fig. 13. Solubilization of $M B P$ and Folch-Pi proteolipid into $A O T /$ isooctane $/ \mathrm{H}_{2} \mathrm{O} /$ microemulsions as a function of the initial $\mathrm{w}_{0}$ content. From [40] [41].

protein-micellar wall interaction, and the protein solubility decreases. Later on, the protein solubility is brought about by the water pool. Therefore, by increasing the $\mathrm{H}_{2} \mathrm{O}$ content the amount of extracted protein should increase again because of the increasing available amount of water, in which the hydrophilic protein can be dissolved.

This dual solubilization mode is represented in Fig. 14 which shows one of the three curves of Fig. 12 qualitatively and schematically decomposed into the two hypothetical components. This decomposition represents only a gross qualitative

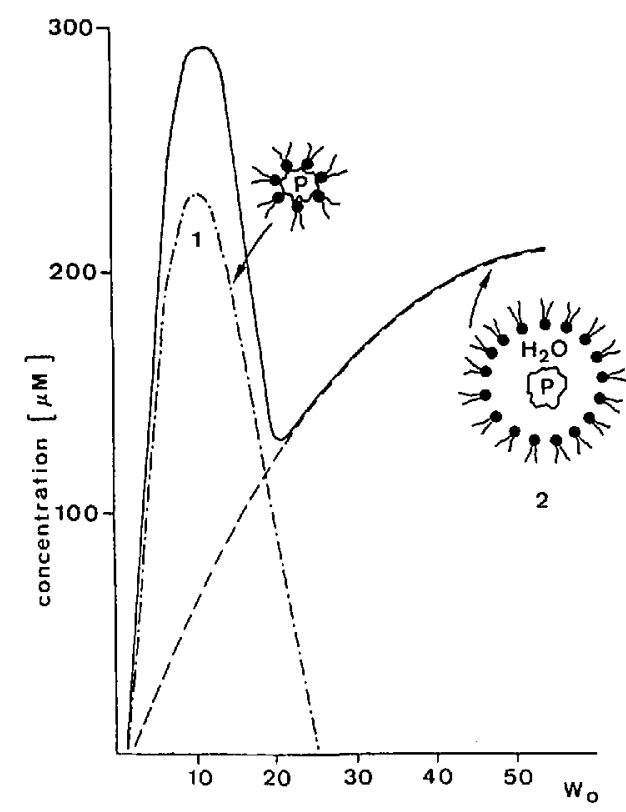

Fig. 14. Decomposition of the extraction curve of ribonuclease (see Fig. 12) in two hypothetical contributions, due to the "micellar-wall solubilization' (Curve I) and to the 'water-pool solubilization' (Curve 2) modes, respectively analysis, but, as we will see later on, it helps to interpret also the solubilization behaviour of several other proteins.

Let us go back to the experimental data, and let us ask the question, whether the micellar enzyme concentrations of Fig. 12 are true equilibrium values. To tackle this problem, we have taken a micellar solution after the lysozyme extraction with $w_{0}=8.8$ (the maximum in Fig. 12) and added different amounts of pure $\mathrm{H}_{2} \mathrm{O}$ to it to get final $w_{\mathrm{o}}$ values, laying in the range between 10 and 50. The $\mathrm{H}_{2} \mathrm{O}$ addition results in a protein precipitation. The remaining micellar enzyme concentrations, obtained for each new $w_{\mathrm{o}}$ value, correspond to the respective values of Fig. 12 (data not shown). This is an indication that indeed equilibrium values were measured.

Another important parameter to point out is the ionization state of the protein in the powder. In the case of the before investigated amino acids, the ionization state in distilled $\mathrm{H}_{2} \mathrm{O}$ is zwitterionic (no significant buffer ions as impurities are present), whereas in the case of the proteins, the ionization state depends generally on the preparation and purification method, and may, therefore, be different for different commercial sources. In the case of the samples in Fig. 12, an aqueous solution of each enzyme showed an acidic $\mathrm{pH}$ and not, as would be expected, a pH corresponding to the protein $\mathrm{pl}$. This demonstrates that the protein is present in a positively charged form, when no buffer ions are added. Its powder, therefore, contains still a small amount of impurities, originated from the last commercial purification steps which determine finally the ionization state of the proteins in their powder. What is the solubilization behaviour of those protein preparations which are 'alkaline', namely, in which the protein powder, dissolved in $\mathrm{H}_{2} \mathrm{O}$, gives a basic $\mathrm{pH}$ ? To answer this question, we have precipitated the protein samples, used in the experiments of Fig. 12, from an alkaline solution (see Experimental). This protein powder, once solubilized afterwards in $\mathrm{H}_{2} \mathrm{O}$, gave a $\mathrm{pH}$ of ca. 910 . Performing the extraction experiments with these 'alkaline' samples, one obtained the results summarized in Fig. 15. The extraction (maximal solubilization at low $\mu_{0}$ ) disappears for ribonuclease and lysozyme. For cytochrome c, however, it is still present, at $c a$. $\mathrm{w}_{\mathrm{o}}=15$. This difference may indicate that for cytochrome $\mathrm{c}$, in contrary to the other two porteins, hydrophobic interaction forces between the protein and the micellar wall play a significant role. The importance of this kind of interactions in the case of cytochrome $c$ has recently been proposed also by Pileni and coworkers [62].

This kind of data have never received attention in the literature so far, but we believe, it may have technical importance, as quite often different commercial preparations of the same protein are 'acidic' or 'basic'. The example of lysozyme is shown in Fig. 16: the batch purchased from Sigma was indeed 'alkaline', and the extraction behaviour (Curve I) was similar to that of the sample made basic in the experiments of Fig. 15: no peak was observed. Once, the 'alkaline' sample from Sigma was made 'acidic' (i.e. precipitated from an acidic solution), the extraction behaviour showed again the expected maxima at small $w_{0}$ value, as shown in Curve 2 of Fig. 16. Curve 3 indicates that the extraction yield of the 'alkine' Sigma lysozyme can also be increased by acidifying the micellar water pools adding $50 \mathrm{~mm} \mathrm{NaHSO}_{4}$. Again, an extraction peak is observed. It is, however, shifted to higher $w_{0}$.

When no extraction peak is seen in the case of an 'alkaline' powder, it is most

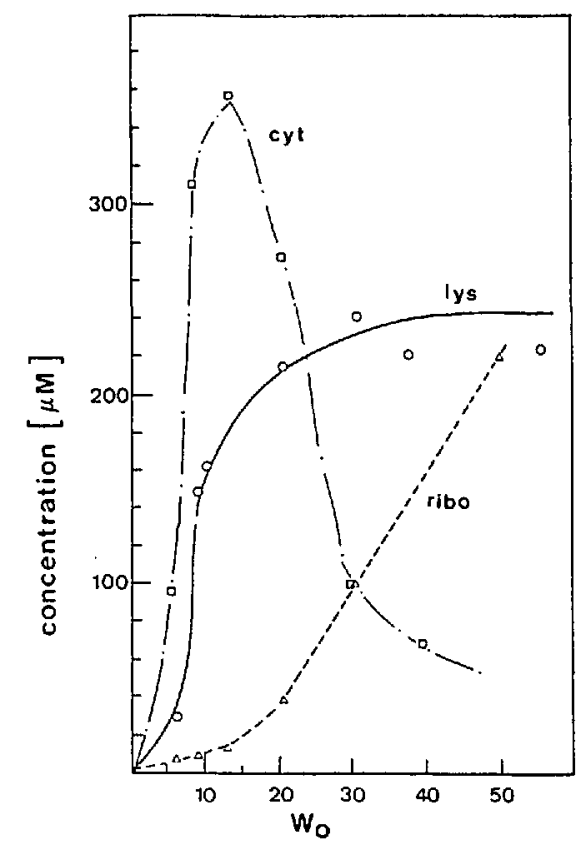

Fig. 15. Extraction of 'alkaline' cytoc'hrome $c$ (cyt), lysozyme (lys), and ribonuclease (ribo) into $50 \mathrm{~mm} \mathrm{AOT} /$ isooctane $/ \mathrm{H}_{2} \mathrm{O}$ as a function of initial $\mathrm{w}$ 。 


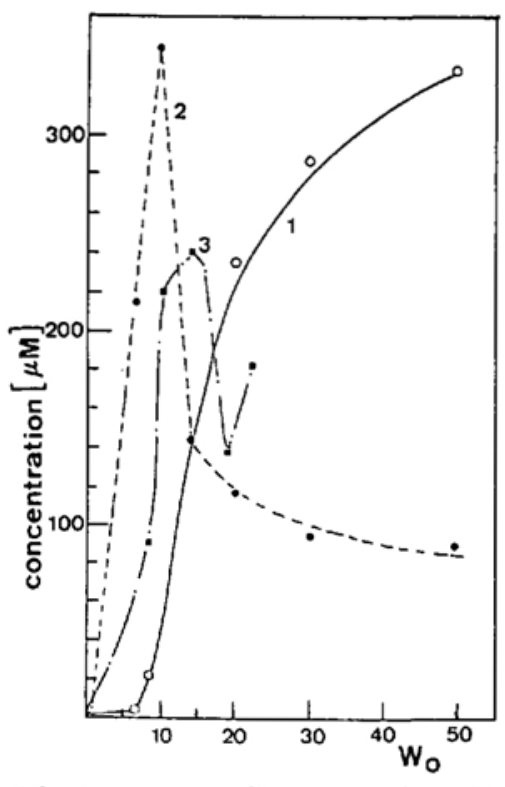

Fig. 16. Extraction of lysozyme from Sigma ('alkaline', Curve I) and of the 'acidified' sample from the same commercial preparation (Curve 2). The Curve 3 gives the extraction behaviour of the same alkaline lysozyme, in which the water pool of the micellar solution contained $50 \mathrm{~mm}$ $\mathrm{NaHSO}_{4}$ with a nominal $\mathrm{pH} 1$.

likely ascribed to the lack of notable electrostatic interactions between the protein and the negatively charged micellar AOT wall. This means, the hypothetical micellar-wall solubilization mode, which assumes favourable electrostatical interactions, is not of great importance.

\subsubsection{The Case of Trypsin,}

\section{$\alpha$-Chymotrypsin, Papain, and Pepsin}

We consider now a group of slightly larger proteins: $\alpha$-chymotrypsin, trypsin, papain, and pepsin. The extraction behaviour as a function of initial $w_{\mathrm{o}}$ is shown in Fig. 17. In contrast to the case of the smaller proteins, no extraction peak at low

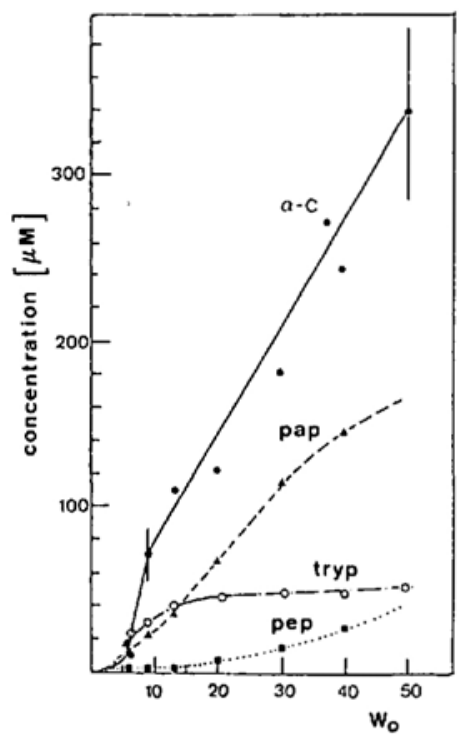

Fig. 17. Extraction of $\alpha$-chymotrypsin $(\alpha-$ C), papain (pap), trypsin (tryp), and pepsin

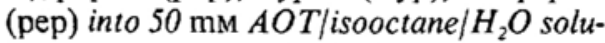
tions as a function of initial $\mathrm{w}_{o}$ $w_{0}$ is observed. This behaviour holds regardless of the ionization state of the protein powders, i.e. by 'acidifying' the protein powder, it was not possible to induce an extraction peak. However, some minor differences could be observed in the larger $w_{0}$ range which we have not analyzed in more detail.

We interprete this extraction mechanism, referring to the model of Fig. 14, as a water pool solubilization mode. It is in fact very likely that in this case the proteins are too large to build up a thermodynamically stable micellar complex with only a small amount of $\mathrm{H}_{2} \mathrm{O}$. Therefore, the solubilization mechanism must be based on properties of the micellar $\mathrm{H}_{2} \mathrm{O}$ content.

The interpretation of the 'sigmoidicity' of the extraction curves is not clear so far. It might be that in the region of small initial $w_{0}$ the micelles are too small to induce the solubilization of the proteins; the extraction begins only at $w_{0}$ values ranging from 5 to 10 . However, Fig. 17 suggests also that the size of the protein is not only affecting the extraction yield, as proteins which are very similar in size (i.e. $\alpha$-chymotrypsin and trypsin) behave quite differently. A competitive, or additional factor, is the hydrophobicity of the protein. To check the importance of the hydrophobic interactions on the extraction behaviour of proteins, we have studied the solubilization yield of bovine serum albumin (BSA). This protein has a molecular weight of $66000 \mathrm{D}$. It is known that BSA forms good complexes with surfactant molecules in aqueous solutions [63] [64]. Extraction data are shown in Table 6. In contrary to the behaviour of the proteins investigated in Fig. 17, one observed a decrease in the BSA extraction curve at large $w_{0}$ values. This behaviour corresponds phenomenologically to the behaviour in Fig. 12. However, its origin lies with all likelihood not in the presence of good favourable electrostatic interactions, but rather in the presence of good hydrophobic forces between the protein and the AOT micellar wall.

Although additional data are necessary to deduce an extraction model which is valuable for all biopolymers, we can make the point that for a given protein the preferential mode of solubilization (i.e. micellar-wall vs. water pool) depends on at least three main factors concerning protein properties: 1) the charge density on the protein surface $(\mathrm{pI}), 2$ ) the molecular weight (protein dimensions), 3) the protein hydrophobicity or hydrophilicity. It is, however, not yet possible to predict in each case which one of these protein properties mainly influences the solubilization be-

Table 6. Extraction of Bovine Serum Albumin (BSA) into $50 \mathrm{~mm} \mathrm{AOT/Isooctane} / \mathrm{H}_{2} \mathrm{O}$ at Different $\mathrm{w}_{o}$ Values

\begin{tabular}{ll}
\hline$w_{\mathrm{o}}$ & $[\mathrm{BSA}]$ in AOT micelles $\left.{ }^{\mathrm{a}}\right)[\mu \mathrm{M}]$ \\
\hline 8.8 & $18.8 \pm 2.3$ \\
15.5 & $46.8 \pm 5.0$ \\
30.0 & $4.5 \pm 0.2$ \\
\hline
\end{tabular}

a) Average of two experiments. haviour. In addition to these parameters there are certainly others which are of great importance, i.e. the symmetry of the charge distribution over the protein surface.

\subsection{Extraction of Protein Mixtures}

To this point, only extraction experiments with single amino acids or proteins were discussed and investigated. It is, however, interesting to see, whether the reverse micelles are also useful in the solubilization of whole protein mixtures, and to what extent they can be used in the separation and purification of specific compounds out of such crude mixtures. So far, the potential selectivity of reverse micelles was investigated using especially the liquid-liquid transfer method. The group at M.I.T. applied this technique, for example, successfully to separate lysozyme, ribonuclease, and cytochrome $\mathrm{c}$ from a synthetic mixture, containing these three proteins [6], or to recover an extracellular alkaline protease from a whole fermentation broth [8]. The dutch group described a method to isolate two different dehydrogenases from whole bacterial cells [14].

To investigate the selectivity of micellar solutions, we carried out experiments using the solid-liquid phase extraction method. This method was so far not directly applied in the micellar separation field. Recently we could demonstrate that by suspending whole crude extracts, i.e. from Escherichia coli [35] or from different vegetable meals [36] directly into AOT/isooctane $/ \mathrm{H}_{2} \mathrm{O}$ micellar solutions, a certain selectivity in the protein solubilization can be achieved. The $\mathrm{H}_{2} \mathrm{O}$ content (i.e. the micellar size) was thereby used as a criterion for protein uptake.

In the following, we will report shortly new results, obtained with the $E$. coli crude extract which was a discarded fraction of the preparation and isolation of the protein thioredoxin (see Experimental).

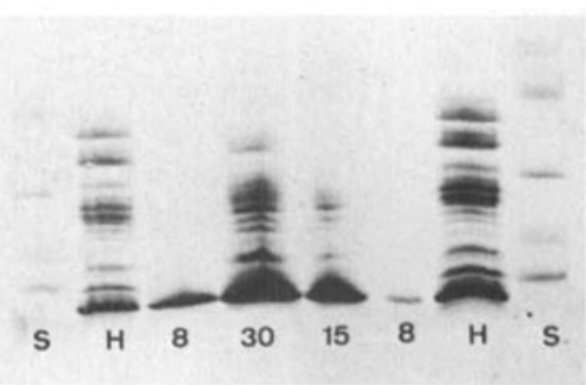

Fig. 18. Size distribution of extracted proteins from an E.coli extract into $100 \mathrm{mM}$ AOT/isooctane $/ \mathrm{H}_{2} \mathrm{O}$ solutions with various $\mathrm{w}_{o}$ values. Standards (S) used in the SDSpolyacrylamide gel electrophoresis: $(14000$ D lactalbumin; 20000 soybean trypsin inhibitor; 30000 carbonic anhydrase; 45000 ovalbumin; 66000 bovine serum albumin (BSA); 94000 phosphorylase); $\mathrm{H}$ indicates the extraction into pure $\mathrm{H}_{2} \mathrm{O}$; the different numbers in the central four gels indicate the $w_{\mathrm{o}}$ values. 
The size distribution of the extracted proteins into the micellar solutions was followed by polyacrylamide gel electrophoresis and determined as a function of the initial $w_{0}$ value. Fig. 18 shows the band distribution of the proteins solubilized into $100 \mathrm{~mm}$ AOT/isooctane $/ \mathrm{H}_{2} \mathrm{O}$ for different $w_{\mathrm{o}}$ values. It is apparent that, with $w_{\mathrm{o}}=8$, only a single narrow band is detected, indicating that only proteins with a molecular weight lower than $14000 \mathrm{D}$ are present. With $w_{0}=15.5$ the number of protein species increases, with a distribution of molecular weight between $20000 \mathrm{D}$ and 30000 D. Finally, at $w_{0} 30$, a large and similar band distribution compared to that obtained after extraction into pure $\mathrm{H}_{2} \mathrm{O}$ is reported.

These results can be understood considering a size exclusion effect which was already mentioned in the experiments with single proteins. The micellar size is thereby the determining parameter allowing the separation of low-molecular-weight from high-molecular-weight compounds in a easy way. The 'micellar cut-off size' appears, however, to be different, when using the same micellar system in the extraction of other crude meals. While in the reported experiments only proteins with a molecular weight smaller than $14000 \mathrm{D}$ could be extracted in $100 \mathrm{~mm}$ AOT/isooctane $/ \mathrm{H}_{2} \mathrm{O}$ $w_{\mathrm{o}}=8$, the same micellar solution could incorporate proteins up to a $M_{\mathrm{r}}$ of $c a$. $18000 \mathrm{D}$ when extracted from sunflower meal, and ever up to a $M_{\text {r }}$ of $30000-40000$ $\mathrm{D}$ when extracted from soybean meal [36]. The reason for this difference lies with all likelihood in the variation of hydrophobicity of the extracted proteins which seems to compete with the micellar 'size-exclusion effect'.

\section{Experimental}

Materials

Amino Acids, Peptides, and Proteins. Ac-Trp-OH Ac-Tyr-OH, Ac-Tyr-OMe, H-Tyr-NH ${ }_{2}$, H-Tyr-Tyr$\mathrm{NH}_{2}$, Z-Ala-Phe-OH, H-Phe-OMe were obtained from Bachem. H-Trp-OH, optically pure and racemic, $\mathrm{H}$ Trp-OMe, Boc-Trp-OH, Z-Trp-OH, Boc-Tyr-OH Boc-O-benzyl-Tyr-OH were purchased from Fluka; all other amino acids and peptides were obtained from Sigma at the highest purity available. Z-Gly-Phe-Trp$\mathrm{OH}$ was synthetized in our laboratory by Dr. $H$. Jeackle and kindly put at our disposal.

Proteins. Eggwhite lysozyme [3.2.1.17] ('acidic') was obtained from Fluka (batch No.62970) the 'basic' sam ple (see text) was from Sigma, grade III, batch No. L7001; pancreatic ribonuclease A [3.1.4.22] ('acidic') and $\alpha$-chymotrypsin [3.4.21.l] ('acidic') were from Sigma; horse heart cytochrome c was from Fluka (puriss., 'neutral', No.30400), and pancreatic trypsin [3.4.21.4] from Boehringer, Mannheim (batch No.109810, 'acidic'). Papain from papaya latex [3.4.22.2] ('acidic', batch No.P-4762, contained NaC and $\mathrm{NaOAc}$ as stabilizers) and pepsin [3.4.2I.I] from pig intestine (batch No.P-6887) were from Sigma. Bovine serum albumin was from Fluka (batch No.05470). Enzymes were used without further purification.

The crude protein extract utilized for the polyacryl. amide gel electrophoresis experiments of Fig. 18 was a by-product from the second step of the purification procedure of thioredoxin from $E$. coli, after gel-permeation and ion-exchange chromatography [65]. The protein mixture were desalted with dialysis against pure $\mathrm{H}_{2} \mathrm{O}$ (cut-off molecular weight: $8000-12000 \mathrm{D}$; -from Specra/Por) and lyophilized, prior to use.

Surfactants. AOT (bis(2-ethylhexyl)sodium sulfosuccinate) was from Sigma, No. DO885, and its purity was considered satisfactory based on UV-absorption spectroscopy and titration. CTAB (cetyltrimethylammonium bromide) was from Sigma, No. $H 5882$ and used without further purification.

The solvents, used for the preparations of revers micelles, i.e. isooctane (2,2,4-trimethylpentane) and $\mathrm{CHCl}_{3}$, as well as hexanol, were UV-grade products from Fluka. All salts used in the transfer experiments were from Fluka or from Merck of the highest degree of purity.

\section{Methods}

\section{Liquid-Liquid Phase Transfer}

Experiments were carried out in tightly stoppered $10-\mathrm{ml}$ glass vials (20-mm diameter). $200 \mu \mathrm{l}$ of an aq enzyme stock soln. (ca. $240 \mu \mathrm{m}$ ) were added to $2.8 \mathrm{ml}$ of an aq. soln. at a given salt concentration and a given $\mathrm{pH}$ (either $20 \mathrm{~mm}$ acetate buffer, $\mathrm{pH} 5$ or $20 \mathrm{~mm}$ borate buffer, $\mathrm{pH} \mathrm{10}$ ). To this aq soln usually $3 \mathrm{ml}$ of a $50 \mathrm{mM}$ AOT/isooctane soln. were added carefully. The vials were then gently shaken for $c a .16$ h at r.t. (ca. 150 rpm), making sure that there was no mechanical mixing between the two phases. Equilibrium was reached generally within $c a .2 \mathrm{~h}$. The experimental error was $\mathrm{ca}$. $5 \%$.

All phase-transfer experiments have been carried ou under standard conditions with $3 \mathrm{ml}$ of aq. phase and 3 $\mathrm{ml}$ of supernatant org. micellar phase having a surface of $3.1 \mathrm{~cm}^{2}$ between the two phases. Obviously, the quant. results are relative to this experimental configuration, however, the qualitative results are valid for any other set of conditions (e.g. a larger volume, or larger interface area). In all these experiments, there is no $\mathrm{H}_{2} \mathrm{O}$ initally in the hydrocarbon phase; thus, $\mathrm{H}_{2} \mathrm{O}$ will be transferred together with the protein from the aqueous phase, till the equilibrium value is reached.

\section{Solid-Phase Extraction}

Extraction experiments from the solid state were carried out in 5-ml tightly stoppered glass vials. Each via contained about 5-30 mg of peptide or enzyme powder (an excess of material was avoided in order to prevent a ignificant loss of $\mathrm{H}_{2} \mathrm{O}$ from the micellar soln. due to absorption on the protein powder), to which $3 \mathrm{ml}$ of 50 $\mathrm{mm}$ AOT/isooctance with an already well determined $\mathrm{H}_{2} \mathrm{O}$ content was added, and shaken at $400 \mathrm{rpm}$ for $\mathrm{co}$. $60-90 \mathrm{~min}$. The undissolved material was separated by centrifugation (3-5 min at $3000 \mathrm{rpm}$ with a Heraeus table centrifuge). The experimental error was within $10-20 \%$.

\section{$\mathrm{H}_{2} \mathrm{O}$ Content}

In all cases, the $\mathrm{H}_{2} \mathrm{O}$ content in the micellar soln. after the phase-transfer or solid-phase-extraction experiments was checked by the Karl Fischer method [66] The experimental error was within $2 \%$

The decrease of the micellar $\mathrm{H}_{2} \mathrm{O}$ content after the solid-phase-extraction experiments, due to $\mathrm{H}_{2} \mathrm{O}$ ad sorption, was in general (except for lysozyme (up to $30 \% \mathrm{H}_{2} \mathrm{O}$ adsorbed), papain (up to $50 \%$ ), and fo some peptides, as indicated in the text) within 10 and $15 \%$

\section{Enzyme or Peptide Concentration}

The enzyme or peptide concentration in the org. phase was measured spectrophotometrically at $280 \mathrm{~nm}$ (258 $\mathrm{nm}$ for the Phe derivatives), assuming the same extinction coefficients as in $\mathrm{H}_{2} \mathrm{O}$.

The Preparation of 'Alkaline' or 'Acidic' Protein Pow ders

To an aq. protein soln. $(200-400 \mu \mathrm{M})$, having an acidic $\mathrm{pH}$, a few drops of $0.1 \mathrm{~m}$ glycine buffer $\mathrm{pH} 10$ were added, till a pH 9.4 was reached. In the case of the acidification of basic aq. protein solns., a few drops of conc. AcOH were added, till a $\mathrm{pH}$ of 3.5 was achieved. Then, the solns. were lyophilized, and the obtained powders were used for the solid-phase-extraction experiments.

SDS-Polyacrylamide Gel Electrophoresis

For the preparation of the soln. for the SDS-polyacrylamide gel electrophoresis, $2 \mathrm{ml}$ of the AOT/isooc- tane $/ \mathrm{H}_{2} \mathrm{O}$ solns., containing the protein after the $\mathrm{ex}$ traction experiments, were dried under vacuum. The dry material was suspended into $500 \mu$ of buffer $(2 \%$ SDS, $5 \%$ mercaptoethanol, $10 \%$ glycerol, $0.001 \%$ bromophenol blue), and heated for several min. The clear soln. was used for the $P A G E$ experiment which was carried out with the Phast-System from Pharmacia.

\section{Concluding Remarks}

Amino acids and proteins can be efficiently solubilized into reverse micellar solutions applying both the liquid-liquid transfer and the solid-liquid phase-extraction method. In the first method, transfer efficiencies into organic micellar phases are mainly determined by: 1) the aqueous ionic strength (salt type and concentration), 2) the aqueous $\mathrm{pH}, 3$ ) the surfactant type (i.e. anionic or ionic) and the surfactant concentration in the organic phase. The solubilization of solute molecules is accompanied by a $\mathrm{H}_{2} \mathrm{O}$ transfer, whose $\mathrm{ki}$ netics and thermodynamic equilibrium values are not affected by the presence of the proteins or amino acids under the investigated conditions. The $\mathrm{H}_{2} \mathrm{O}$ extractions is mainly influenced by the ionic strenght in the aqueous phase.

The parameter studied in the solid-liquid phase extraction method is the initial micellar $\mathrm{H}_{2} \mathrm{O}$ content. It essentially determines the droplet size in the microemulsions.

The fact that $\mathrm{H}_{2} \mathrm{O}$-soluble proteins, such as ribonuclease $\mathrm{A}$ or lysozyme, are quantitatively transferred into supernatant AOT/ hydrocarbon solutions is quite surprising. Recently, Maestro and Luisi [22] published a first attempt to explain the high transfer efficiencies on the basis of classic thermodynamics. This work was later extented [20] [23]. Somewhat different approaches were published recently by Bratko et al. [67] and Woll and Hatton [68]. A theoretical understanding of transfer processes is in fact important both for the basic and the applicative aspects of the problem. Actually, several questions are most interesting: one is related with the effect of salt type and salt concentration on the transfer Why, for example, exhibit $\mathrm{KCl}$ and $\mathrm{NaCl}$ a quite different effect on the solubility behaviour of the same protein? Partly, the effect of salt on the solubility of proteins has been studied already in aqueous solutions, and concepts like 'salting-in' and 'salting-out' [69] are well understood in the protein field. One should extend these concepts to the case of reverse micelles, although it is not yet clear, whether the same principles will be valid. Another interesting aspect is the influence of the protein size on the extraction behaviour. Since micelles are swelling and dynamic entities, it is not apparent at first sight, why the 'micellar wall' solubilization mode should apply only to small proteins like lysozyme and ribonuclease and not to proteins a little larger such as papain or chymotrypsin. 
Here again, thermodynamic studies will of fer the only way to propose a rationale.

The presented extraction experiments showed that both electrostatic and hydro phobic interactions between the solubilized compounds and the surfactant molecules are essential in the solubilization process. From the experimental results it is, however, not generally possible to predict which of these two interaction modes will dominate the solubilization. Moreover, one has to stress again that the nature of the solubilized $\mathrm{H}_{2} \mathrm{O}$ exhibits, particularly at low $w_{0}$, novel properties, compared to those of bulk $\mathrm{H}_{2} \mathrm{O}$. This is also indicated by the fact, that $\mathrm{H}_{2} \mathrm{O}$-insoluble proteins and peptides are solubilized into micellar solutions under those conditions (small $u_{\circ}$ ) [41], that enzymes in reverse micelles usually display their maximal activity in the $w_{0}$ range 6-12 [42-45], and that $\mathrm{H}_{2} \mathrm{O}$ in this $w_{0}$ range freezes well below $0^{\circ}[53]$.

From the applicative point of view, there are several questions still to be answered, in order to get to a final conclusion. One of the most important question is, whether one can modulate the dominating extraction parameters $\left(w_{o}\right.$, salt type and concentration, $\mathrm{pH}$, type of surfactant, type of solvent, and temperature) in order to achieve a specific separation of protein mixtures. The so far available data dealing with these variables lead to a positive answer. However, more studies are necessary in this field which will also foster progress in a large number of basic science areas. Another question is related to the back-transfer process. It is the procedure, by which the protein, once extracted into the micellar solution, is brought back into an aqueous solution, or, more generally, recovered in a form which can be processed. Surprisingly, very few data are available on the subject, so that the question, whether proteins can all be recovered with high yield and without denaturation, is still unanswered. We have published some preliminary data [30] [31] [37], showing that under certain conditions ribonuclease $A$ or $\alpha$-chymotrypsin can be recovered with good enzymatic activity. The group in Wageningen has sketched a reactor procedure for a discontinuous batch reactor extracting and recovering $\alpha$-amylase in an active form [12]. Last problem which is relavant for biotechnology, and which has not been solved - or even faced yet - is connected with the back-transfer: it is the question, whether and to what extent the protein can be recovered in a form which is free from surfactant. This is critical, particularly when working with surfactants which are not allowed by, for example, the F.D.A. It will be probably difficult to purify completely the recovered protein from AOT or similar surfactants. A solution to the problem may be offered using biodegradable and biocompatible surfactants. Preliminary data relative to the use of lecithins for the extraction of proteins from the solid state are available in our group [70]. Although lecithins are presently too expen- sive for a large-scale biotechnological application, this may indicate the way to proceed in the field.

Received: April 24, 1990

[1] P. L. Luisi, C. Laane, Trends Bioterhnol. 1986, 4 153

[2] P. Lüthi, P. L. Luisi, J. Am. Chem. Soc. 1984, 106 7285

[3] A. Pessina, P. Lüthi, P. L. Luisi, J. Prenosil, Y.-S Zhang, Helv. Chim. Acta 1988, 7I, 44

[4] K. L. Kadam, Enzyme Microb. Technol. 1986, 8 266

[5] K.E. Göklen, T.A. Hatton, Biotec/mol. Prog $1985,1,69$.

[6] K.E. Göklen, T. A. Hatton, Sep. Sci. Tecimol $1987,22,831$.

[7] T. A. Hatton, in 'Ordered Media in Chenical Separations, ACS Symposium Series 342', Eds. W. L. Hinze and D. W. Armstrong, American Chemical Society, Washington, DC, 1987, p. 170.

[8] R.S. Rahaman, J. Y. Chce, J. M.S. Cabral, T. A Hatton. Biolechnol. Prog. 1988, 4.218.

[8a] J. M. Woll, T. A. Hatton, M. L. Yarmush, Biotect nol. Prog. 1989, 5, 57.

[9] E. Sheu, K. E. Göklen, T. A. Hatton, S. H. Chen Biotechnol. Prog. 1986, 2, 175.

[10] E. B. Leodidis, T.A. Hatton, Langmuir 1989, 5, 741.

[11] T.A. Hatton, in 'Surfactant-Based Separation Processes', Eds. J.F. Scamehorn and J.H. Harwell, Marcel Dekker, New York-Basel, 1989, p. 55 .

[12] M. Dekker, K. van'1 Riet, S. R. Weijers, J. W.A. Baltussen, C. Laane, B. H. Bijsterbosch, Chem Eng. J. 1986, 33, B27.

[13] M. Dekker, K. van't Riet, B.H. Bijsterbosch, R. B. G. Wolbert, R. Hilhorst, AICHEI. 1989, 35, 321 .

[14] S. Giovenco, F. Verheggen, C. Laane, Enzyme Microh. Technol 1987, 9470

[15] R. B.G. Wolbert, R. Hilhorst, G. Voskuilen, H. Nachtegasl, M. Dekker, K. van't Riet, B.H. Bijsterbosch, Eur. J. Biochem. 1989, 184,627.

[16] M. Dekker, R. Hilhorst, C. Laane, Anal. Biochem. $1989,178,217$.

[17] P. D. ]. Fletcher, J. Chem. Soc., Faraday Trans. I $1986,82,2651$.

[18] P. D. I. Fletcher, D. Parrott, J. Chem. Soc., Faraday Trans. $/$ 1988, 84, 1131

[19] D. W. Armstrong, W. Li, Anal. Chem. 1988, 60 86

[20] M. Caselli, M. Maestro, G. Morea. Biotechnol. Prog. 1988, 4, 102

[21] P. Bruno, M. Caselli, P.L. Luisi, M. Maestro, A Traini, J. Phys Chem 1990, 94, 5908.

[22] M. Maestro, P. L. Luisi, 6th International Symposium on Surfactants in Solution, August $18-22$, 1986. New Delhi.

[23] M. Carelli, P. L. Luisi, M. Maestro, R. Roselli, J. Phys. Chem. 1988, 92, 3899.

[24] M. Casclli, P. L. Luisi, R. Roselli, A. Traini, Anal Lett. 1987, 20, 941

[25] P. Plucinski, W. Nitsch, Ber. Bunsenges. Phys Chem 1989, 93, 994

[26] C. Jolivalt, M. Minier, H. Renon, J. Colloid Interface Sci. 1990, 135.85.

[27] A. Dossena, V. Rizzo, R. Marchelli, G. Casnati, P. L. Luisi, Biochim. Bioplys. Acta 1976, 446, 493

[28] P. L. Luisi, F. Henniger, M. Joppich, A. Dossena, G. Casnati, Biochem. Biophys. Res. Commun $1977,74,1384$.

[29] P. L. Luisi, F. J. Bonner, A. Pellegrini, P. Wiget, R Wolf, Helv. Chim. Acta 1979, 62, 740.

[30] P. Meier, E. Imre, M. Fleschar, P. L. Luisi, in 'Surfactants in Solution', Eds. K. L. Mittal and B. Lindman, Plenum Press, New York London, 1984, Vol. 2, pp. 999.

[31] P. L. Luisi, V.E. Imre, H. Jäckle, A. Pande, in 'Topies in Pharmaceutical Sciences'. Eds. D. D. Breimer and P. Speiser, Elsevier, Amsterdam, 1983, pp. 243

[32] C. Grandi, R. E. Smith, P. L. Luisi, J. Biol. Chem $1981,256,837$.
[33] M.E. Leser, G. Wei, P.L. Luisi, M. Macstro. Biochem. Biophys. Res. Commm. 1986, 135, 629.

[34] M.E. Leser, P. L. Luisi, Biotechnol. Techmiques $1989,3,149$.

[35] M. E. Leser, G. Wei, P. Lüthi, G. Haering, A Hochkoeppler, E. Blöchliger, P. L. Luisi, J. Chim. Phys. 1987, 84,1113.

[36] M.E. Leser, P. L. Luisi, S. Palmieri, Biotechnol Bioeng. 1989, 34, 1140.

[37] G. Marcozzi, N. Correa, P. L. Luisi, M. Casclli submitted to J. Colloid Interface Sci.

[38] A.V. Levashov, Y. L. Khmelnitski, N. L. Klyachko, K. Martinek, in 'Surfactants in Solution", Eds. K. L. Mittal and B. Lindman, Plenum Press, New York-London, 1984, Vol. 2, pp. 1069

[39] N. L. Klyachko, A.V. Levashov, K. Martinek, Mol. Biol. (Moscow) 1984, I8, 1019.

[40] C. Nicot, M. Vacher, M. Vincent, J. Galley, M Waks, Biochemistry, 1985, 24, 7024

[41] A. Delahodde. M. Vacher, C. Nicot, M. Waks FEBS Lett. 1984, $172,343$.

[42] P. L. Luisi, L. J. Magid, CRC Crit. Rer. Biochem. 1986, 20, 409

[43] P.L. Luisi, M. Giomini, M.P. Pileni, B.H Robinson, Biochim. Biophys. Acra 1988, 947, 209.

[44] K. Martinek, A.V. Levashov, N. L. Klyachko, Y. L. Khmelnitski, I. V. Berezin, Eur. J. Biochem. 1986, 155, 453.

[45] P. L. Luisi, B. Steinmann-Hoffmann, Meth. Enzymol. 1987, 136, 188

[46] K. Martinek, I.V. Berezin, Y.L. Khmelnitski, N. L. Klyachko, A. V. Levashov, Biocatalysis $1987, l, 9$.

[47] H. F. Eicke, Topics Curr. Chem. 1980, 87,85.

[48] B. H. Robinson, C. Toprakcioglu, J.C. Dore, P. Chicux, J. Chem. Soc.. Faraday Trans. I 1984, 80 13.

[49] H. McDonald, B. Bedwell, E. Gulari, Langmuir 1986, 2, 704.

[50] K.F. Thompson, L.M. Gierasch, J. Am. Chem. Soc. 1984, 106,3648

[5H] A. Llor, P. Rigny, J. Am. Chem. Soc. 1986, $10 \mathrm{~S}$ 7533

[52] K. Galvin, J. A. McDonald, B. H. Rohinson, Col loids Surfaces 1987, 25. 195.

[53] H. Hauser, G. Hacring, A. Pande, P. L. Luisi, $J$ Phis. Chem. 1989, 93, 7869.

[54] O. A. El Seoud, R.C. Vieira, J. Colloid Interface Sci. 1983, 93, 289

[55] J. B. Behr, J. M. Lehn, J. Am. Chem. Soc. 1973, 95 6108.

[56] F. M. Menger, K. Yamada, J. Am. Chem. Soc $1979,101,6731$

[57] C. R. Cantor, P. R. Schimmel, Eds., in 'Biophysical Chemistry', W. H. Freeman, New York, 1980 Vol. 2; P. D. Boycr, Ed., 'The Enzymes', 3rd edn. Academic Press. New York, 1971, Vol.3: H. A Sober, Ed., 'CRC Handbook of Biochemistry', 2nd edn., The Chemical Rubber Co., 1970.

[58] M.E. Leser, Ph.D. dissertation, ETH Nr. 8697 Eidgenössische Technische Hochschule, Zürich, 1988

[59] P. H. von Hippel, T. Schleich, Acc. Chem. Res. $1969,2,257$

[60] 'Handbook of Chemistry and Physics', 67th edn. CRC Press, Boca Raton. 1986, C-702.

[61] P. Schurtenberger, personal communication.

[62] P. Brochette, C. Petit, M.P. Pileni, J. Phy's. Chem $1988,92,3505$

[63] M.N. Jones, H. A. Skinner, E. Tipping, Biochem. J. 1975, 147, 229.

[64] K. Takeda, M. Shigeta. K. Aoki, J. Colloid Interface Sci. 1987, 117, 120

[65] R.M. Thomas, R. Boos, P. L. Luisi, in 'Thioredoxin and Glutharedoxin System: Structure and Function', Ed. A. Holmgren, Raven Press, New York, 1986, pp. 87 .

[66] K. Fischer, Angen'. Chem. 1935, 48, 394.

[67] D. Bratko, A. Luzar, S. H. Chen, J. Chem. Phys $1988,89,545$

[68] J.M. Woll, T.A. Hatton, Bioprocess Enginecring $1989,4,193$

[69] T. Arakawa, S. N. Timashefr, Biochemistry 1984, 23, 5912.

[70] Q. Peng, P. L. Luisi, Eur. J. Biochem. 1990, 188 471. 